\title{
On the genus Mesopontonia Bruce, 1967 (Crustacea: Decapoda: Palaemonidae) in Korea, with the description of a new species
}

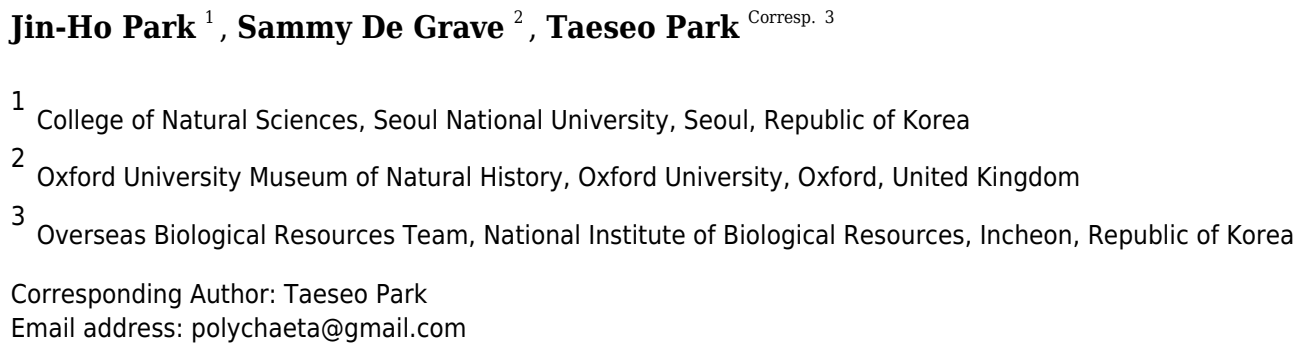

Mesopontonia verrucimanus and Mesopontonia kimwoni sp. nov. are recorded from highlatitude temperate waters in Munseom Islet, Jejudo Island, Republic of Korea, with both species collected on gorgonians and sponges by trimix diving between 50 and $75 \mathrm{~m}$ depth. Mesopontonia kimwoni sp. nov. is morphologically allied to $M$. brevicarpus, but can be distinguished by the cutting edges of the fingers of the first chela being entire. Significant morphological variation in the rostrum as well as the second pereiopods is documented in $M$. verrucimanus, although cytochrome $c$ oxidase subunit I (COI) barcode analysis proves this to be infra-specific variation. A key to species of the genus Mesopontonia is provided. 


\section{On the genus Mesopontonia Bruce, 1967 (Crustacea:}

2 Decapoda: Palaemonidae) in Korea, with the

3 description of a new species

4

5 Jin-Ho Park ${ }^{1}$, Sammy De Grave ${ }^{2}$, Taeseo Park ${ }^{3}$

6

$7 \quad{ }^{1}$ College of Natural Sciences, Seoul National University, Seoul, Republic of Korea

$8{ }^{2}$ Oxford University Museum of Natural History, Oxford University, Oxford, United Kingdom

$9{ }^{3}$ Overseas Biological Resources Team, National Institute of Biological Resources, Incheon,

10 Republic of Korea

11

12 Corresponding Author:

13 Taeseo Park ${ }^{3}$

14 Hwangyeong-ro 42, Seo-gu, Incheon, 22689, Republic of Korea

15 Email address: polychaeta@gmail.com

16 
17 On the genus Mesopontonia Bruce, 1967 (Crustacea: Decapoda: Palaemonidae) in Korea, with the description of a new species

${ }^{1}$ College of Natural Sciences, Seoul National University, Seoul, Republic of Korea

2 Oxford University Museum of Natural History, Oxford University, Oxford, United Kingdom

${ }^{3}$ Overseas Biological Resources Team, National Institute of Biological Resources, Incheon,

26 Republic of Korea

27

Corresponding Author:

29 Taeseo Park ${ }^{3}$

Hwangyeong-ro 42, Seo-gu, Incheon, 22689, Republic of Korea

Email address: polychaeta@gmail.com

\section{Abstract}

Mesopontonia verrucimanus and Mesopontonia kimwoni sp. nov. are recorded from high-latitude temperate waters in Munseom Islet, Jejudo Island, Republic of Korea, with both species collected on gorgonians and sponges by trimix diving between 50 and $75 \mathrm{~m}$ depth. Mesopontonia kimwoni sp. nov. is morphologically allied to M. brevicarpus, but can be distinguished by the cutting edges of the fingers of the first chela being entire. Significant morphological variation in the rostrum as well as the second pereiopods is documented in M. verrucimanus, although cytochrome $c$ oxidase subunit I (COI) barcode analysis proves this to be infra-specific variation. A key to species of the genus Mesopontonia is provided.

\section{Introduction}

The deep-sea palaemonid shrimp fauna of the Indo-West Pacific is relatively well documented, with to date 23 genera and about 84 species recorded from depths of more than $100 \mathrm{~m}$ by trawling and dredging (Bruce 1991; De Grave \& Fransen 2011; Kou et al. 2016; Li et al. 2008; Marin \& Chan 2014; Mitsuhashi \& Chan 2006; Okuno 2017; Wang et al. 2015). Among them is the rarely recorded genus, Mesopontonia Bruce, 1967 which can be distinguished from related genera by the combination of the absence of both supraorbital and antennal teeth on the carapace, as well as the absence of an exopod on the third maxilliped (Bruce 1967; Bruce 1995; Chace \& Bruce 1993).

The most recent classification of carideans by De Grave and Fransen (2011) listed six species in the genus, namely M. gorgoniophila Bruce, 1967 (type species), M. gracilicarpus Bruce, 1990, M. brucei Burukovsky, 1991, M. monodactylus Bruce, 1991, M. verrucimanus Bruce, 
northern part of the South China Sea (Bruce, 1967), in association with two species of the gorgonian genus Melithaea Milne Edwards, 1857 (Cnidaria: Octocorallia: Melithaeidae) in depths of 117-183 m (Fig. 1A). Since then, it has been sparingly reported upon from New Caledonia, the Philippines, and eastern Australia within depths of 130 to $270 \mathrm{~m}$ (Bruce 1979; Bruce 1984; Bruce 1985; Bruce 1991). Mesopontonia gracilicarpus has been reported from New Caledonia and the Chesterfield Islands in depths of 226-600 m (Bruce 1990; Bruce 1991; Li \& Bruce, 2006). The southwestern Indian Ocean species, M. brucei was recorded from depths of 415-460 m from about $850 \mathrm{~km}$ south of Madagascar (Burukovsky, 1991). Mesopontonia monodactylus was described from the Loyalty Islands (Bruce 1990), associated with species of the hexactinellid sponge genus Pheronema Leidy, 1868 (Porifera: Hexactinellida: Pheronematidae) from $460 \mathrm{~m}$ (Bruce 1990); M. verrucimanus was reported from the Tanimbar Islands, Indonesia in depths of 184-186 m (Bruce 1996). Finally, another western Indian Ocean species, M. brevicarpus was recorded from off La Réunion from $270 \mathrm{~m}$ (Li \& Bruce, 2006).

Jejudo Island, the largest island in Korea, is located about $80 \mathrm{~km}$ off the southwestern coast of the mainland (Fig. 1B). In summer, the Tsushima current mixes with low-salinity, highturbidity waters from the Yangtze River to influence the environment around Jejudo Island. In winter, the Yangtze River discharge reduces, resulting in a higher local salinity (Rebstock and Kang, 2003; Lim et al. 2019). Munseom Islet (Fig. 1C) is located off the south coast of the main island, and consists of volcanic rocks covered with rich invertebrate communities (Cho et al. 2014; Lutaenko et al. 2019; Lee et al. 2019), with a maximum depth of less than 75m. Thus far, only five symbiotic palaemonid shrimps have been reported from the Jejudo Island area (Koo \& Kim 2003; Lee \& Ko 2011; Lee \& Ko 2014; Park et al. 2019a; Park et al. 2019b), although many more remain unrecorded and will be covered in future contributions.

During a faunal survey for deep-water invertebrate species from previously unexplored habitats around Jejudo Island in 2015-2020, numerous specimens of Mesopontonia were collected from gorgonians and sponges by trimix SCUBA diving between 50-75 m depth. Detailed examination of their morphology as well as a phylogenetic analysis including related genera indicated that these belong to M. verrucimanus (new record for Korea) and an undescribed species in the same genus, constituting the most northerly record for the genus, as well as the first for temperate waters in the Western Pacific.

In this study, we thus describe both Mesopontonia species and present an identification key for the genus Mesopontonia. To support systematic studies for deep-sea palaemonid shrimps, molecular analyses and ecological information through direct observations are provided.

\section{Materials \& Methods}

Sample collection. Specimens of Mesopontonia and other palaemonid shrimps were collected by trimix diving at depths between 50-75 m around Munseom Islet, Jejudo Island, organized by Seoul National University (SNU) and the National Institute of Biological Resources (NIBR) during 2015-2020. Comparative material used in the phylogenetic part was collected by conventional SCUBA diving at depths between 10-30 m in Korea (2018-2019), Palau (2019), 
96 Philippines (2018-2019), and Taiwan (2016), organized by Academia Sinica, University of the 97 Philippines Visayas (UPV), Korea Institute of Ocean Science \& Technology (KIOST), Marine

98 Biodiversity Institute of Korea (MABIK), and SNU. All specimens were collected together with 99 their host invertebrates and preserved in $80 \%$ ethanol. Specimens are deposited in the Marine

100 Arthropod depository Bank of Korea, Seoul National University, Seoul (MADBK), Seoul

101 National University, Seoul (SNU), National Institute of Biological Resources, Incheon (NIBR)

102 and the Zoological Collections of the Oxford University Museum of Natural History, Oxford

103 (OUMNH.ZC).

104 Morphological examination. Shrimps were isolated from the host invertebrate using forceps, 105 with their morphological characteristics observed using stereo microscopes (Leica M205C and

$106 \mathrm{M} 125$, Germany) and a light microscope (Olympus BX51, Japan). Digital illustrations were done

107 using a microscope digital camera (Leica MC170, Germany), Helicon focus software (Helicon

108 focus 7.5.6, Ukraine) and drawing tablet (Wacom Intuos Pro PTH-660, China) with Adobe

109 Illustrator software (Adobe Systems, USA), following Coleman (2006).

110 Molecular data and phylogenetic analysis. Molecular phylogenetic analyses were performed to

111 understand the phylogenetic position of the new species, as well as the genus more broadly. Two

112 species of Mesopontonia (M. verrucimanus and the new species) and 12 deep-sea species from

113 the genera Altopontonia Bruce, 1990, Anchistioides Paulson, 1875, Bathymenes Kou, Li \&

114 Bruce, 2016, Cuapetes Clark, 1919, Echinopericlimenes Marin \& Chan, 2014, Lipkemenes Bruce

115 \& Okuno, 2010, Palaemonella Dana,1852, Paraclimenes Bruce, 1995, Periclimenes Costa, 1844

116 and Thaumastocaris Kemp, 1922 were selected as the ingroup. Stenopus hispidus (Olivier, 1811)

117 was used as an outgroup (Table 1). Total genomic DNA was extracted from eggs or pleopod

118 tissue using the QIAamp ${ }^{\circledR}$ DNA Micro Kit (QIAGEN, Hilden, Germany), following the

119 manufacturer's instructions. Partial sequences of the COI ( $658 \mathrm{bp})$ and 16S ( 538bp) markers

120 were amplified via polymerase chain reaction (PCR) with the primers jgHCO2198/jgLCO1490

121 (Geller et al. 2013) and 16S-ar/16S-1472 (Crandall \& Fitzpatrick 1996; Palumbi et al. 2002),

122 respectively. PCR reactions and sequence data analysis were performed following Park et al.

123 (2019a).

124 Zoobank registration. The electronic version of this article in Portable Document Format (PDF)

125 will represent a published work according to the International Commission on Zoological

126 Nomenclature (ICZN), and hence the new names contained in the electronic version are

127 effectively published under that Code from the electronic edition alone. This published work and

128 the nomenclatural acts it contains have been registered in ZooBank, the online registration

129 system for the ICZN. The ZooBank LSIDs (Life Science Identifiers) can be resolved and the

130 associated information viewed through any standard web browser by appending the LSID to the

131 prefix http://zoobank.org/. The LSID for this publication is:

132 urn:lsid:zoobank.org:pub:3CB43670-472F-49AE-80F2-EAE9597E12BD. The online version of

133 this work is archived and available from the following digital repositories: PeerJ, PubMed

134 Central and CLOCKSS.

135

Peer] reviewing PDF | (2020:06:50042:2:0:NEW 19 Sep 2020) 


\section{Results}

\section{Taxonomy}

138 Family Palaemonidae Rafinesque, 1815

139 Genus Mesopontonia Bruce, 1967

140 Mesopontonia verrucimanus Bruce, 1996

141 Figs. 2-7

142

143

144

145

146

147

148

149

150

151

152

153

154

155

156

157

158

159

160

161

162

163

164

165

166

167

168

169

170

171

172

173

174

175
Mesopontonia verrucimanus Bruce, 1996: 198, 216-218, figs. 8, 29c (type locality: Tanimbar Islands, Indonesia, $\left.7^{\circ} 59^{\prime} \mathrm{S}, 133^{\circ} 02^{\prime} \mathrm{E}, 184-186 \mathrm{~m}\right)$.

Material examined. 2 males, 2 females (pocl 2.0-2.5, R 1+7-8/0); Dec. 20, 2015; Munseom Islet, Jejudo Island, Korea (3313'36"N 126³4'9"E), 55 m, on Raspailia (Raspaxilla) hirsuta Thiele, 1898, leg. JH Park (MADBK 120533_001); 2 males, 1 female (pocl 2.5, R 1+6-8/0); Apr. 12, 2017; same location (3313'39"N 126³4'7"E), 58 m, on $R$. (R.) hirsuta, leg. JH Park (MADBK 120533_002); 1 male, 2 females (pocl 2.3-2.5, R 1+7-8/0-1); Apr. 12, 2017; same location $\left(33^{\circ} 13^{\prime} 39^{\prime \prime N} 126^{\circ} 34^{\prime} 7^{\prime \prime E}\right), 58 \mathrm{~m}$, on $R$. (R.) hirsuta, leg. JH Park (OUMNH.ZC.2018-0304-06); 1 male, 4 females (pocl 2.5-3.5, R 1+7-8/0-1); May 30, 2017; same location (3313'36"N 126³4'9"E), 54 m, on Ellisella cf. limbaughi Bayer \& Deichmann, 1960, leg. JH Park (MADBK 120533_003); 1 male, 1 female (pocl 2.5, R 1+7-8/1); Jan. 18, 2018; same location $\left(33^{\circ} 13^{\prime} 36^{\prime \prime N} 126^{\circ} 34^{\prime} 9^{\prime \prime E}\right), 60 \mathrm{~m}$, on E. cf. limbaughi, leg. JH Park (MADBK 120533_004); 2 males, 3 females (pocl 2.0-2.5, R 1+7-8/0-1); Jan. 18, 2018; same location (3313'36"N 126 34'9"E), 60m, on E. cf. limbaughi, leg. JH Park (NIBRIV00008377600000837764); 1 female (pocl 3.0, R 1+8/1); Mar. 31, 2018; same location (33²13'36"N 126³4'9"E), 60m, on E. cf. limbaughi, leg. JH Park (MADBK 120533_005); 1 male (pocl 2.6, R 1+8/0); Jun. 20, 2018; same location (3313'31"N 126³4'11"E), 60m, on E. cf. limbaughi, leg. JH Park (MADBK 120533_006); 1 male, 2 females (pocl 2.78-2.87, R 1+7-8/0-2); Jun. 20, 2018; same location (3313'31"N 126³4'11"E), 60m, on E. cf. limbaughi, leg. JH Park (NIBRIV0000837778-NIBRIV0000837780); 1 male, 1 female, 1 ovigerous female (pocl 2.673.47, R 1+6-8/0xl); Jun. 21, 2018; same location (3313'31"N 126³4'11"E), 55m, on E. cf. limbaughi, leg. JH Park (NIBRIV0000862982-NIBRIV0000837784); 1 male (pocl 3.13, R 1+7/0); Sep. 12, 2018; same location (33¹3'29"N 126³3'52"E), 60m, on Myriopathes lata (Silberfeld, 1909), leg. JH Park (NIBRIV0000862987); 1 male (pocl 3.41, R 1+7/0); Sep. 13, 2018; same location (3313'29"N 126³3'52"E), 60m, on E. cf. limbaughi, leg. JH Park (NIBRIV0000862988); 2 ovigerous females (pocl 3.7-3.8, R 1+8-9/0); Sep. 13, 2018; same location (3313'29"N 126³3'52"E), 60m, on Cirrhipathes cf. anguina (Dana, 1846), leg. JH Park (NIBRIV0000862989-0000837790); 2 males (pocl 3.2, R 1+8-9/0); Jul. 26, 2019; same location (3313'35"N 126³4'11"E), 60m, on E. cf. limbaughi, leg. JH Park (NIBRIV0000862991-0000837792); 1 ovigerous female (pocl 3.4, R 1+9/1); Jul. 27, 2019; same location (3313'35"N 12634'11"E), 55m, on E. cf. limbaughi, leg. JH Park (NIBRIV0000862993); 1 female (pocl 1.5, R 1+7/0); Aug. 16, 2019; same location (3313'41"N 126³4'6"E), 53m, on C. anguina, leg. JH Park (NIBRIV0000862995); 1 male, 3 females, 2 
176 ovigerous females (pocl 1.5-3.7, R 1+8-9/0-1); Oct. 22, 2019; same location (33¹3'37"N

177 126 34'11"E), 67m, on E. cf. limbaughi, leg. JH Park (NIBRIV0000862996-

178 NIBRIV0000863001); 2 males, 1 female (pocl 2.4-3.7, R 1+8-9/0-2); Jan. 15, 2020; same



180 120533_007); 3 females (pocl 2.5-2.8, R 1+7-8/0); Jan. 15, 2020; same location (33¹3'34"N

181 126 33'45"E), 75m, on C. anguina, leg. JH Park (SNU KR JH1100-1102); 1 male (pocl 2.5, R

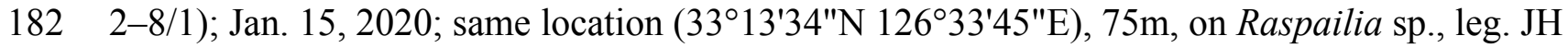

183 Park (SNU KR JH1095); 1 female (pocl 2.3, R 1-8/0); Jan. 15, 2020; same location (3313'34"N

184 126 33'45"E), 75m, on Raspailia sp., leg. JH Park (SNU KR JH1096); 1 female (pocl 2.9, R 1-

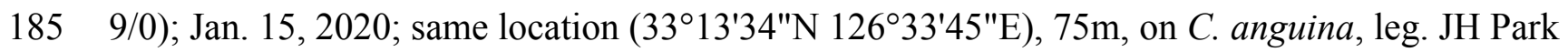

186 (SNU KR JH1 104).

187 Description of Korean specimens. Body (Fig. 2) small-sized, subcylindrical form. Rostrum

188 (Figs. 2 and 3A-D) straight, horizontal, almost as long as pocl, reaching or overreaching distal

189 end of antennular peduncle, 6-9 dorsal teeth, spaced along entire length, $0-2$ ventral teeth.

190 Carapace (Figs. 2 and 3A-D) smooth, glabrous, with epigastric tooth at anterior 0.3 of pocl;

191 without supraorbital and antennal teeth; inferior orbital angle produced; hepatic tooth large,

192 acute, extending to anterior margin of carapace; pterygostomial angle bluntly rounded.

193

194

Abdomen (Fig. 2) smooth; pleura of first five segments rounded; sixth pleura with pointed posterolateral angle, posteroventral angle subacute.

Telson (Figs. 2 and 3E, F) about 0.75 of pocl, 4.0 times as long as proximal width; two pairs of small dorsal spiniform setae at 0.4 and 0.65 of telson length respectively, with three pairs of posterior spiniform setae, lateral pair shortest, medial pair long and stout.

Eye (Figs. 2 and 4A) with hemispherical cornea, dorsolaterally with nebenauge, diameter about 0.20 of pocl.

Antennule (Figs. 2 and 4B) with proximal peduncle bearing distolateral tooth, with small

201

202

203

204

205

206

207

208

209

210

211

212

213 acute tooth at ventromedial margin; stylocerite narrow, bearing sharp point, reaching to 0.45 times of proximal segment; intermediate segment short, 0.4 times of proximal segment length, 0.8 of distal segment; upper flagellum biramous, proximal five segments fused, lower flagellum slender, filiform.

Antenna (Figs. 2 and 4C) basicerite with sharp pointed distodorsal margin; ischiocerite and merocerite unarmed; carpocerite reaching to about 0.4 of scaphocerite length; scaphocerite 4 times as long as maximal width, lateral margin rounded, medial margin convex, distolateral tooth large, at 0.9 of lamella length.

Mouthparts typical for genus. Third maxilliped (Fig. 4D) without exopod, reaching to middle of carpocerite; ultimate segment about 0.4 of antepenultimate segment length, tapering distally, with transverse rows of setae; penultimate segment about 0.6 of antepenultimate segment length, with sparsely row of long setae ventromedially; ischiomerus completely fused to basis, antepenultimate segment feebly compressed distally, with long setae ventromedially; coxa with

214 rounded medial lobe, with rounded lateral plate. 
215 First pereiopod (Figs. 2, 5A and 5B) reaching to distal end of scaphocerite; fingers about 0.81 216 of palm length, tips hooked, cutting edge entire, with transverse row of setae and group of 217 terminal setae; palm ventrolaterally with transverse row of serrulate setae; carpus 1.3 times

218 length of chela with row of serrulate setae along distomesial margin; merus as long as carpus;

219 ischium about 0.7 times length of merus; basis and coxa without special features.

220

221

Second pereiopods (Figs. 2A, 5C-G) well developed, dissimilar in shape, unequal in size. Major second pereiopod (Fig. 5C-E) overreaching distal end of rostrum by middle of propodus;

222 chela about 0.63 of pocl, with group of terminal setae; fingers about 0.5 of palm length; dactylus

223

224 slender, about 3.6 times longer than proximal depth, distally curved with acute tip, proximally with two acute teeth at 0.3 and 0.40 , distally entire without dorsolateral flange; fixed finger with

225

226 acute tip, proximally with two small teeth at 0.2 and 0.3 , distally entire; palm subcylindrical, about 4.0 times longer than distal width, covered with minutely blunt tubercles and simple setae;

227

228

229

230

231

232

233

234

235 carpus about 0.45 of palm length, about 2 times longer than distal width; merus about 2.0 times as long as carpus, as long as palm length, about 6.2 times longer than distal width; ischium as long as carpus length, about 6.0 times longer than distal width; basis and coxa without special features.

Minor second pereiopod (Fig. 5F, G) slightly overreaching distal end of scaphocerite; chela about 0.4 of pocl, 0.7 of major chela length, with group of terminal setae; fingers about 0.7 of palm length, distally curved with acute tips, cutting edge entire; palm subcylindrical, about 3 times longer than distal width, smooth slightly tapering proximally; carpus about 1.4 of palm length, about 0.9 of chela length, about 5.6 times longer than distal width; merus about 1.1 times

236

237 as long as carpus length, about 7.8 times longer than distal width; ischium about 1.1 times as long as merus length, about 7.8 times longer than distal width; basis and coxa without special features.

239

Ambulatory pereiopods (Figs. 2 and 6) subequal in shape and size. Third pereiopod (Fig. 6A, B) overreaching distal end of rostrum by distal end of propodus; dactylus about 0.26 of propodus length, about 4.2 times longer than proximal width, not biunguiculate; propodus about 10 times longer than distal width, ventral border with four distolateral spiniform setae including pair distoventral one, with long setae distally, with distodorsal plumose setae and distal setae; carpus about 0.54 times length of propodus, unarmed; merus as long as carpus length, unarmed; ischium about 0.5 length of propodus, unarmed; basis and coxa without special features. Fourth and fifth pereiopods (Fig. 6C-F) similar to third pereiopod.

Uropod (Figs. 2 and 3E) overreaching distal end of telson; exopod with distolateral tooth and movable acute tooth. Variation. Bruce (1996) described Mesopontonia verrucimanus based on a single specimen (holotype), with nine dorsal teeth, unarmed ventrally and markedly unequal, dissimilar second pereiopods. TheKorean specimens exhibit morphological variation in rostral dentition and the major second pereiopod. The number of dorsal and ventral rostral teeth (Figs. 2 and $3 \mathrm{~A}-\mathrm{D}$ ) varies from 6-9 and 0-2 respectively. A single specimen (Fig. 3D) harbours two epigastric teeth on the carapace. Several specimens (Fig. 2B) bear two symmetrical second pereiopods, which 
255

256

257

258

259

260

261

262

263

264

265

266

267

268

269

270

271

272

273

274

275

276

277

278

279

280

281

282

283

284

285

286

287

288

289

290

291

292

are very similar to the minor second pereiopods in the original description and in other Korean specimens (Fig 2A).

Color in life. Whole body and appendages almost transparent with scattered emerald green chromatophores (Fig. 7); longitudinal pale red band along the ventral surface of the body from the carapace to the fifth abdominal somite.

Geographical distribution. Presently known from the Tanimbar Islands (Indonesia) and Jejudo Island (Republic of Korea) (Fig. 1).

Habitat and host. The present specimens were obtained from gorgonian and sponge colonies below $50 \mathrm{~m}$ (Fig. 14A, B), with the deepest samples from $75 \mathrm{~m}$ depth. The present specimens demonstrate a lack of host specificity and the species cannot be considered as restricted to gorgonians, as previously postulated. Most specimens were collected on the orange colored sea whip, Ellisella cf. limbaughi (Bayer \& Deichmann 1960), with further specimens obtained on the white colored gorgonian, Cirrhipathes cf. anguina (Dana, 1846), as well as the orange colored sponge, Raspailia (Raspaxilla) hirsuta Thiele, 1898. A single specimen was collected on the white colored antipatharian, Myriopathes lata (Silberfeld, 1909).

Mesopontonia verrucimanus can be immediately separated from most other species in the genus which have a biunguiculate dactylus of ambulatory pereiopods, except M. monodactylus with which it shares a non-biunguiculate dactylus. M. monodactylus differs from $M$. verrucimanus primarily by having a distinct dorsolateral flange on the chela of the major second pereiopod (Bruce 1991; Bruce 1996).

\section{Mesopontonia kimwoni sp. nov.}

urn:lsid:zoobank.org:act:BBA317A3-7140-4D97-BCF4-DB6EEF6617F5

Figs. 8-12

\section{Material examined.}

Type material. Holotype. 1 ovigerous female (pocl 2.5, R 1+8/2); Jun. 21, 2018; Munseom Islet,


Park (NIBRIV0000862985). Paratype. 1 ovigerous female (pocl 2.8, R 1+8/2); Aug. 16, 2019; same location ( $\left.33^{\circ} 13^{\prime} 41^{\prime \prime N} 126^{\circ} 34^{\prime} 6^{\prime \prime E}\right), 53 \mathrm{~m}$, on M. lata, leg. JH Park (NIBRIV0000862994). Description. Body (Fig. 8) small-sized, subcylindrical form. Rostrum (Figs. 8 and 9A) straight, horizontal, almost as long as pocl, reaching or slightly beyond end of antennular peduncle, 8 dorsal teeth, along entire length, 2 subterminal ventral teeth.

Carapace (Fig. 8) smooth, glabrous, with epigastric tooth at anterior 0.3 of pocl; without supraorbital and antennal teeth; inferior orbital angle produced; hepatic tooth large, acute, extending to anterior margin of carapace; pterygostomial angle bluntly rounded.

Abdomen (Fig. 8) smooth; pleura of first five segments rounded; sixth pleura with pointed posterolateral angle, posteroventral angle subacute. 
293

294

295

296

297

298

299

300

301

302

303

304

305

306

307

308

309

310

311

312

313

314

315

316

317

318

319

320

321

322

323

324

325

326

327

328

329

330

331

332

Telson (Figs. 8 and 9D) 0.8 of pocl, 4.0 times as long as proximal width; two pairs of small dorsal spiniform setae at 0.45 and 0.7 of telson length respectively, with three pairs of posterior spiniform setae, lateral pair shortest, medial pair long and stout.

Eye (Figs. 8 and 9B-C) with hemispherical cornea, dorsolaterally with nebenauge, diameter about 0.23 of pocl.

Antennule (Fig. 9B) with proximal peduncle bearing distolateral tooth, with small acute tooth at ventromedial margin; stylocerite narrow, bearing sharp point, reaching to 0.45 times of proximal segment; intermediate segment short, 0.3 times of proximal segment length, subequal to distal segment; upper flagellum biramous, proximal four segments fused, lower flagellum slender, filiform.

Antenna (Figs. 8 and 9B) basicerite with sharp pointed distodorsal margin; ischiocerite and merocerite unarmed; carpocerite reaching to about 0.4 of scaphocerite length; scaphocerite 4 times as long as maximal width, lateral margin rounded, medial margin convex, distolateral tooth large, at 0.9 of lamella length.

Mouthparts not dissected. Third maxilliped (Fig. 9F) without exopod, reaching to 0.7 of carpocerite; ultimate segment about 0.35 of antepenultimate segment length, tapering distally, with transverse rows of setae; penultimate segment about 0.7 of antepenultimate segment length, with sparsely row of long setae ventromedially; ischiomerus completely fused to basis, antepenultimate segment feebly compressed distally, with long setae ventromedially; coxa with rounded medial lobe, with rounded lateral plate.

First pereiopod (Figs. 8 and 9A, B) overreaching distal end of scaphocerite; fingers about 0.6 of palm length, tips hooked, cutting edge entire, with transverse row of setae and group of terminal setae; palm ventrolaterally with transverse row of serrulate setae; carpus 1.1 times length of chela with row of serrulate setae along distomesial margin; merus 1.1 times length of carpus; ischium about 0.5 times length of merus; basis and coxa without special features.

Second pereiopods (Figs. 8 and 10C-G) well developed, similar in shape, unequal in size. Major second pereiopod (Fig. 10C-E) overreaching distal end of rostrum by middle of propodus; chela about 1.3 times as long as pocl, with group of terminal setae; fingers about 0.4 of palm length; dactylus slender, about 3.8 times longer than proximal depth, distally curved with acute tip, proximally with two blunt teeth at proximal 0.3 and 0.4 , distally entire without dorsolateral flange; fixed finger with distally curved with acute tip, proximally with single acute tooth at 0.4 , distally entire; palm subcylindrical, about 4.2 times longer than distal width, covered with minutely blunt tubercles and short simple setae; carpus about 0.4 of palm length, about 2.8 times longer than distal width; merus about 2.1 times as long as carpus, about 0.8 of palm length, 7.0 times longer than distal width; ischium subequal to carpus length, about 7.0 times longer than distal width; basis and coxa without special features.

Minor second pereiopod (Fig. 10F, G) overreaching distal end of rostrum by end of carpus; chela about 0.7 of pocl, 0.7 of major chela length, with group of terminal setae; fingers about 0.7 of palm length, with distally curved with acute tips, cutting edge entire; palm subcylindrical, about 3.75 times longer than distal width, smooth, slightly tapering proximally; carpus about 1.3 
333 of palm length, about 0.75 of chela length, about 7.2 times longer than distal width; merus about

3341.1 times as long as carpus length, about 9 times longer than distal width; ischium about 0.9 of

335

336

337

338

339

340

341

342

343

344

345

346

347

348

349

350

351

352

353

354

355

356

357

358

359

360

361

362

363

364

365

366

367

368

369

370

371

372 merus length, about 10 times longer than distal width; basis and coxa without special features.

Ambulatory pereiopods (Figs. 8 and 11) subequal in shape and size, only third pereiopod with distodorsal plumose setae and distal serrulate setae on propodus. Third pereiopod (Fig. 11A, B) overreaching distal end of rostrum by distal half of propodus; dactylus about 0.2 of propodus, about 4 times longer than proximal width, about 0.65 of corpus length, biunguiculate; propodus about 0.8 of pocl, 16 times longer than distal width, ventral border with four distolateral spiniform setae including single distoventral one, with long setae distally; carpus about 0.4 times length of propodus, unarmed; merus about 0.9 times length of propodus, unarmed; ischium about 0.5 length of propodus, unarmed; basis and coxa without special features.

Fourth pereiopod (Fig. 11C, D) with dactylus about 0.2 times length of propodus, about 4 times longer than proximal width, about 0.65 of corpus length, biunguiculate; propodus with four distolateral spiniform setae including single distoventral one, with long simple setae distally; carpus about 0.45 times length of propodus, unarmed; merus subequal to propodus length, unarmed; ischium about 0.46 length of propodus; basis and coxa without special feature. Fifth pereiopod (Fig. 11E) similar to fourth pereiopod.

Uropod (Figs. 11D) overreaching distal end of telson; exopod with distolateral tooth and movable acute tooth.

Etymology. The specific name "kimwoni" is in honor of Dr. Kim, Won, professor in the School of Biological Sciences, Seoul National University. He made a considerable contribution to the systematics of Korean crustaceans.

Color in life. Whole body and appendages almost transparent (Figs. 12 and 13); longitudinal red bands along the ventral surface of the body from antennular peduncle to the fifth abdominal somite; tiny white and red chromatophore scattered along the dorsal surface of cornea of eyes, proximal segment of antennular peduncle and abdomen.

Type locality. Munseom Islet, Jejudo Island, Korea

Geographical distribution. Presently only known for the type locality.

Habitat. The two specimens of M. kimwoni sp. nov. were collected from the gorgonian antipatharian, Myriopathes lata (Silberfeld, 1909) in 53-55 m (Fig. 14C).

Remarks. Based on the presence of the biunguiculate dactyli of ambulatory pereiopods, the new species is morphologically allied to four species: M. brevicarpus Li \& Bruce, 2006, M. brucei Burukovsky, 1991, M. gorgoniophila Bruce, 1967, and M. gracilicarpus Bruce, 1990; and can be easily separated from the remaining two species in the genus (M. monodactylus Bruce, 1991, M. verrucimanus Bruce, 1996) which have simple dactyli. The new species differs from $M$. gorgoniophila by the straight distodorsal carina in the major second pereiopod (vs. oblique distodorsal carina in M. gorgoniophila), with two teeth on the cutting edge of dacytlus of major second pereiopod (vs. with single tooth in M. gorgoniophila), dorsolateral dactylar flange of major second pereiopod absent (vs. present in M. gorgoniophila), as well as the proportions of the carpus of the minor second pereiopod (about 1.3 time palm length in M. kimwoni sp. nov. vs. 
373 about 0.8 in M. gorgoniophila). The new species differs from M. gracilicarpus primarily by the 374 relative short size of the carpus of the first pereiopods (about 1.1 times the chela length in $M$. 375 kimwoni sp. nov., vs. about 1.4 in M. gracilicarpus), as well as the proportions of the carpus of 376 the minor second pereiopod ( 0.8 times chela length in M. kimwoni sp. nov. vs. about 1.5 in $M$.

377

378

379

380

381

382

383

384

385

386

387

388

389

390

391

392

393

394

395

396

397

398

399

400

401

402

403

404

405

406

407

408

409

410

411

412

gracilicarpus). The new species can be distinguished from $M$. brucei by the presence of a minute tubercle on the chela of the major second pereiopod (vs. absent in M. brucei), relatively long fingers of first pereiopod (about 0.6 of palm length in M. kimwoni sp. nov. vs. about 0.5 in $M$. brucei), relatively short carpus of major second pereiopod (about 0.4 of the palm length in $M$. kimwoni sp. nov. vs 0.6 in $\mathrm{M}$. brucei) and the relatively long carpus of the minor second pereiopod (about 1.3 times the palm length in M. kimwoni sp. nov. vs. about 0.9 in M. brucei).

M. kimwoni sp. nov., appears most closely related to the west Indian species, M. brevicarpus, sharing a similar rostral formulation, a tuberculate major second pereiopod chela, as well as the ratio of the ambulatory pereiopods. Both species can be most easily distinguished on the basis of the combination of the following characters, 1) fingers of first chela with entire cutting edge (vs. fine pectinated serrations subapically on both fingers in M. brevicarpus); 2) hepatic tooth reaching to the anterior margin of the carapace (vs. reaching or extending to anterior margin of carapace in M. brevicarpus) and 3) the finger of minor chela being about 0.7 of the palm length (vs. fingers subequal to palm in M. brevicarpus).

Bruce (1996) suggested two further new species may be present in the genus, one collected from Indonesia (Bruce, 1996), as well as the juvenile specimen assigned to M. gorgoniophila in Bruce (1985), both however were left unnamed. Given their incomplete or juvenile status these taxa are not considered herein, but are unlikely to be the same species as M. kimwoni, as the details of the first and second pereiopods are different.

\section{Molecular data analyses}

Fragments of 658 and $462 \mathrm{bp}$ were obtained for the COI and $16 \mathrm{~S}$ markers, respectively. The multiple sequence alignment revealed that the K2P distance between the five specimens of $M$. verrucimanus which showed minor morphological variations in the dentition of the rostrum and proportions of the second pereiopods fall within an intraspecific range, being $0-0.5 \%$ (Table 2). The intraspecific divergence between both specimens of M. kimwoni sp. nov. was higher at $1.1 \%$ (Table 2).

To eludicate the phylogenetic position of the genus, an analysis was performed on 22 specimens of 16 species of 12 genera (Table 1). The ML and BI analyses showed the same topology (Fig. 15), and the combined phylogenetic tree clearly demonstrated the monophyly of Mesopontonia with high support values $(\mathrm{BP}=100, \mathrm{PP}=100)$. Furthermore, their distant relationship was supported by the K2P distance, which was $13.6 \%$ (Table 2).

From the concatenated tree in the present analysis,the genera Mesopontonia and Paraclimenes are postulated to be sister taxa with high support values $(\mathrm{BP}=100, \mathrm{PP}=92)$, indicating that they are more genetically related to each other than the remaining analysed genera, supported by morphological similarities. 


\section{Discussion}

415 The present study explored the commensal palaemonid fauna of Jejudo Island, recording

416 Mesopontonia kimwoni sp. nov. and M. verrucimanus at higher latitude temperate waters than

417 the genus was previously known from. While the six species previously known in the genus had

418 been reported from between 117 and $600 \mathrm{~m}$ depth by trawling and dredging (Bruce 1967; Bruce

419 1979; Bruce 1984; Bruce 1985; Bruce; 1990a; Bruce 1991; Bruce, 1996; Burukovsy, 1991; Li \&

420 Bruce, 2006), the present specimens were collected from shallower depths of less than $75 \mathrm{~m}$. As

421 they were directly collected with technical SCUBA diving equipment, more details are available

422 on their habitat and ecology, whilst color patterns are recorded for the first time for the genus as

423 a whole.

424 Mesopontonia kimwoni sp. nov. can be distinguished from all other Mesopontonia species by

425 the combination of the biunguiculate dactylus of the ambulatory pereiopods, the lack of a

426 dorsolateral dactylar flange on the major second chela, the relatively long carpus of the minor

427 second pereiopod and the entire cutting edge of fingers of first chela. Specimens of $M$.

428 verrucimanus exhibited minor morphological variation in rostral dentition and proportions of the 429 major second pereiopod, but all specimens are clearly conspecific.

430 Due to its rarity, Mesopontonia had not been previously included in family level phylogenies

431 (e.g. Kou et al. 2013; Gan et al. 2015; Horká et al. 2016), but is herein shown to be

432 phylogenetically close to Paraclimenes. This is also supported by a relatively similar

433 morphology with both antennal and supraorbital teeth being absent; and the epigastric and

434 hepatic teeth being present. Nevertheless, Paraclimenes can be readily distinguished from

435 Mesopontonia by the presence of a well-developed exopod on the third maxilliped (Bruce 1995).

436

437

Key to species of Mesopontonia Bruce, 1967 (Adapted from Bruce, 1996; Li \& Bruce, 2006)

438

1. Dactylus of ambulatory pereiopods simple.

- Dactylus of ambulatory pereiopods biunguiculate.

2. Major second pereiopod with dorsolateral dactylar flange M. monodactylus Bruce, 1991

441 - Major second pereiopod without dorsolateral dactylar flange ........ verrucimanus Bruce, 1996

3. Major second pereiopod with dorsolateral dactylar flange M. gorgoniophila Bruce, 1967

443 - Major second pereiopod without dorsolateral dactylar flange .4

444

445

4. Carpus of minor second pereiopod longer than chela M. gracilicarpus Bruce, 1990

- Carpus of minor second pereiopod shorter than chela 5

447

5. Carpus of minor second pereiopod shorter than palm M. brucei Burukovsky, 1991

448

- Carpus of minor second pereiopod longer than palm

6. Fingers of first chela with pectinated serrations, subapically..M. brevicarpus Li \& Bruce, 2006

- Fingers of first chela with clear entire cutting edge; R. 1+8/2 . M. kimwoni sp. nov. 450

\section{Abbreviations used in text, tables and figures}

452 
453 BI Bayesian Inference

454 BP Maximum likelihood bootstrap percentage

455 K2P Kimura 2-parameter

456 ML Maximum likelihood

457 POCL postorbital carapace length

458 PP Bayesian posterior probabilities

459 R Rostrum formula; formulation of epigastric tooth and teeth on rostrum.

460

461 Acknowledgements

462 We thank Dr. Hyi-Seung Lee (KISOT, Korea) and Dr. Wilfredo L. Campos (UPV, Philippines)

463 for their invitation and management in Philippines fieldwork. We are also grateful to Dr. Benny

464 K. K. Chan (Academia Sinica, Taiwan) for the invitation to participate in the exploration of

465 Green Island, Taiwan. Authors also wish to thank to Prof. Sung-Jin Hwang (Woosuk University, 466 Korea) and Dr. Hyung June Kim (MABIK, Korea) for helping identification of the host species, 467 and Dr. Sanghui Lee (MABIK, Korea) and Dr. Damin Lee (SNU, KOREA) for their assistance 468 in field survey, and to Ms. Eunseon Jun (Sahmyook University, Korea) for helping with 469 molecular experiments. TP would like to also thank Ms. Yun Kyoung Kim for her worthful 470 assistance with the color drawing in figure 13. We extend sincere thanks to Capt. Jong Moon 471 Choi (Blue Research, Korea) for his kind help of photographing the habitats and guidance in 472 Deep-Sea Research Diving.

473 
474

475

476

477

478

479

480

481

482

483

484

485

486

487

488

489

490

491

492

493

494

495

496

497

498

499

500

501

502

503

504

505

506

507

508

509

510

511

512

513

514

515

516

517

518

519

520

521

\section{References}

Bayer FM, and Elisabeth D. 1960. The Ellisellidae (Octocorallia) and their bearing on the zoogeography of the eastern Pacific. Proceedings of the Biological Society of Washington 73:175-182.

Bruce AJ. 1967. Notes on some Indo-Pacific Pontoniinae III-IX. Descriptions of some new genera and species from the western Indian Ocean and the South China Sea. Zoologische Verhandelingen 87:1-73.

Bruce AJ. 1979. Records of some pontoniine shrimps from the South China Sea. Cahiers de l'IndoPacifique 1:215-248.

Bruce AJ. 1984. The pontoniine shrimp fauna of Australia. Australian Museum Memoir 18:195-218 DOI:10.3853/j.0067-1967.18.1984.385.

Bruce AJ. 1985. Decapod Crustacea: Pontoniinae (MUSORSTOM II). Mémoires du Muséum national d'Histoire naturelle (A) Zoologie 133:229-260.

Bruce AJ. 1990a. Crustacea Decapoda: Deep-sea palaemonoid shrimps from New Caledonian Waters. In: Crosnier A, ed. Résultats des Campagnes MUSORSTOM Vol 6. Paris: Mémoires du Muséum national d'Histoire naturelle, A, Zoologie, 149-215.

Bruce AJ. 1990b. Periclimenes franklini sp. nov., a new deep-sea shrimp from the Coral Sea (Crustacea: Decapoda: Palaemonidae). Beagle: Records of the Museum and Art Galleries of the Northern Territory 7:55-64.

Bruce AJ. 1991. Crustacea Decapoda: Further deep-sea palaemonoid shrimps from New Caledonian waters. In: Crosnier A, ed. Résultats des Campagnes MUSORSTOM Vol 9. Paris: Mémoires du Muséum national d'Histoire naturelle, A, Zoologie, 299-411.

Bruce AJ. 1995. A synopsis of the Indo-West Pacific genera of the Pontoniinae (Crustacea: Decapoda: Palaemonidae). Konigstein: Koeltz Scientific Books.

Bruce AJ. 1996. Crustacea Decapoda: Palaemonoid shrimps from the Indo-West Pacific region mainly from New Caledonia. In: Crosnier A, ed. Résultats des Campagnes MUSORSTOM, Volume 15. Paris: Mémoires du Muséum national d'Histoire naturelle, 197-267.

Bruce AJ, and Okuno J. 2010. Designation of a new genus Lipkemenes, with supplementary description and range extension of its type species, L. lanipes (Kemp, 1922) (Decapoda, Palaemonidae). In: Fransen CHJM, De Grave S, and Ng PKL, eds. Studies on Malacostraca: Lipke Bijdeley Holthuis Memorial Volume. Leiden: Brill, 159-171 DOI:10.1163/9789047427759_008.

Burukovsky RN. 1991. New and rare species of shrimps from the south-west part of the Indian Ocean [in Russian]. Zoologicheskii Zhurnal 70:36-41.

Chace FAJ, and Bruce AJ. 1993. The Caridean Shrimps (Crustacea: Decapoda) of the Albatross Philippine Expedition, 1907-1910, Part 6: Superfamily Palaemonoidea. Smithsonian Contributions to Zoology:1-152.

Cho I-Y, Kang D-W, Kang J, Hwang H, Won J-H, Paek WK and Seo S-Y. 2014. A study on the biodiversity of benthic invertebrates in the waters of Seogwipo, Jeju Island, Korea. Journal of Asia-Pacific Biodiversity 7:e11-e18 DOI:10.1016/j.japb.2014.03.003.

Clark AH. 1919. Some necessary changes in crustacean nomenclature. Proceedings of the Biological Society of Washington 32:199.

Coleman CO. 2006. Substituting time-consuming pencil drawings in arthropod taxonomy using stacks of digital photographs. Zootaxa 1360:61-68 DOI:10.11646/zootaxa.1360.1.4.

Costa OG. 1844. Su due nuovi generi di Crostacei decapodi macrouri. Annali delle Accademia de-gli Aspiranti Naturalisti, Napoli 2:285-292.

Crandall KA, and Fitzpatrick JF, Jr. 1996. Crayfish molecular systematics: using a combination of procedures to estimate phylogeny. Systematic Biology 45:1-26 DOI:10.1093/sysbio/45.1.1.

Dana JD. 1846. United States Exploring Expedition during the years 1838-1842. Zoophytes 7:1-740 DOI:10.5962/bhl.title.69333. 
522

523

524

525

526

527

528

529

530

531

532

533

534

535

536

537

538

539

540

541

542

543

544

545

546

547

548

549

550

551

552

553

554

555

556

557

558

559

560

561

562

563

564

565

566

567

568

569

570

Dana JD. 1852. Conspectus crustaceorum, \&c. Conspectus of the Crustacea of the exploring expedition under Capt. C. Wilkes, U.S.N. Macroura. Proceedings of the Academy of Natural Sciences of Philadelphia 6:10-28.

De Grave S. 1999. Variation in rostral dentition and telson setation in a saltmarsh population of Palaemonetes varians (Leach) (Crustacea: Decapoda: Palaemonidae). Hydrobiologia 397:101108 DOI:10.1023/A:1003698615660.

De Grave S, and Fransen CHJM. 2011. Carideorum Catalogus: The Recent Species of the Dendrobranchiate, Stenopodidean, Procarididean and Caridean Shrimps (Crustacea: Decapoda). Zoologische Mededelingen 85:195-588.

De Grave S, and Sakihara TS. 2011. Further records of the anchialine shrimp, Periclimenes pholeter Holthuis, 1973 (Crustacea, Decapoda, Palaemonidae). Zootaxa 2903:64-68 DOI:10.11646/zootaxa.2903.1.7.

Duriš Z, and Bruce AJ. 1995. A revision of the 'petitthouarsii' species-group of the genus Periclimenes Costa, 1844 (Crustacea: Decapoda: Palaemonidae). Journal of Natural History 29:619-671 DOI:10.1080/00222939500770221.

Ďuriš Z, and Šobáňová A. 2020. Deep sea palaemonid shrimps of Papua New Guinea (Crustacea: Decapoda: Palaemonidae). In: Corbari L, Ahyong ST, and CHAN T-Y, eds. Deep-Sea Crustaceans from Papua New Guinea. Tropical Deep-Sea Benthos 31. Paris: Muséum national d'Histoire naturelle, 369-401.

Gan ZB, Li XZ, Chan T-Y, Chu KH and Kou Q. 2015. Phylogeny of Indo-West Pacific pontoniine shrimps (Crustacea: Decapoda: Caridea) based on multilocus analysis. Journal of Zoological Sysyematics and Evolutionary Research 53:282-290 DOI:10.1111/jzs.12108.

Geller J, Meyer C, Parker M, and Hawk H. 2013. Redesign of PCR primers for mitochondrial cytochrome c oxidase subunit I for marine invertebrates and application in all-taxa biotic surveys. Molecular Ecology Resources 13:851-861 DOI:10.1111/1755-0998.12138.

Horká I, De Grave S, Fransen CHJM, Petrusek A, and Ďuriš Z. 2016. Multiple host switching events shape the evolution of symbiotic palaemonid shrimps (Crustacea: Decapoda). Scientific Reports 6:26486 DOI:10.1038/srep26486.

Kemp SW. 1922. Notes on Crustacea Decapoda in the Indian Museum, XV. Pontoniinae. Records of the Indian Museum 24:133-288.

Koo H, and Kim W. 2003. First report of palaemonid shrimp Onycocaris callyspongiae (Decapoda: Caridea: Palaemonidae) from Korea. The Korean Journal of Systematic Zoology 19:251-255.

Kou Q, Li XZ, Chan T-Y, Chu KH and Gan Z. 2013. Molecular phylogeny of the superfamily Palaemonoidea (Crustacea :Decapoda : Caridea) based on mitochondrial and nuclear DNA reveals discrepancies with the current classification. Invertebrate Systematics 27, 502-514 DOI:10.1071/IS13005.

Kou Q, Li XZ, and Bruce AJ. 2016. Designation of a new genus Bathymenes for the deep-sea pontoniine shrimps of the 'Periclimenes alcocki speciesgroup' (Decapoda, Caridea, Palaemonidae), with a checklist of the species assigned to the genus. Chinese Journal of Oceanology and Limnology 34:170-176 DOI:10.1007/s00343-015-4359-4.

Kwak M-T, Seo G-H, Cho Y-K, Kim B-G, You SH, and Seo J-W. 2015. Long-term comparison of satellite and in-situ sea surface temperatures around the Korean Peninsula. Ocean Science Journal 50:109-117 DOI:10.1007/s12601-015-0009-1.

Lee KH, and Ko HS. 2011. First records of tow pontoniid shrimps (Crustacea: Decapoda: Caridea: Palaemonidae) from Korea. The Korean Journal of Systematic Zoology 27:239-245 DOI:10.5635/KJSZ.2011.27.3.239.

Lee KH, and Ko HS. 2014. Occurence of pontoniine shrimp, Periclimenes brevicarpalis (Decapoda: Caridea: Palaemonidae) in Korean waters. Animal Systematics, Evolution and Diversity 30:319322 DOI:10.5635/ASED.2014.30.4.319.

Peer] reviewing PDF | (2020:06:50042:2:0:NEW 19 Sep 2020) 
571

572

573

574

575

576

577

578

579

580

581

582

583

584

585

586

587

588

589

590

591

592

593

594

595

596

597

598

599

600

601

602

603

604

605

606

607

608

609

610

611

612

613

614

615

616

617

618

619

620

Lee SH, and Ko HS. 2013. The first record of Conchodytes nipponensis (De Haan, 1844) (Crustacea: Decapoda: Palaemonidae) associated with pen shell Atrina pectinata (Linnaeus, 1767) (Mollusca: Bivalvia) from Korea. Journal of Species Research 2:1-6 DOI:10.12651/JSR.2013.2.1.001.

Lee T, Stöhr S, Bae YJ and Shin S. 2019. A new fissiparous brittle star, Ophiacantha scissionis sp. nov. (Echinodermata, Ophiuroidea, Ophiacanthida), from Jeju Island, Korea. Zoological Studies 58:e8 DOI:10.6620/ZS.2019.58-08.

Li XZ, and Bruce AJ. 2006. Further Indo-Pacific palaemonoid shrimps (Crustacea: Decapoda: Palaemonoidea), principally from the New Caledonian region. Journal of Natural History 40:611-738 DOI:10.1080/00222930600763627.

Li XZ, Mitsuhashi M, and Chan T-Y. 2008. Deep-sea pontoniines (Decapoda: Palaemonidae) from the Philippine "panglao 2005" expedition, with descriptions of four new species. Journal of Crustacean Biology 28:385-411 DOI:10.1163/20021975-99990384.

Lim N-L, Lee H-M, Jeung H-D, Noseworthy RG, Jung S, Choi K-S. 2019. Early larval development and annual gametogenesis of the brooding oster Ostrea cicumpicta (Pilsbry, 1904) in the shallow subtidal benthis ecosystem in Jeju Island, off the south coast of Korea. Zoological studies 58:e29 DOI:10.6620/ZS.2019.58-29.

Lutaenko KA, Noseworthy RG and Choi K-S. 2019. Marine bivalve mollusks of Jeju Island (Korea). Part 1. The Korean Journal of Malacology 35:149-238 DOI:10.9710/kjm.2019.35.2.149.

Marin I, and Chan T-Y. 2014. Deep water echinoid-associated pontoniine shrimp "Periclimenes hertwigi Balss, 1913" species group (Crustacea: Decapoda: Caridea: Palaemonidae): species review, description of a new genus and species from Philippines. Zootaxa 3835:301-324 DOI:10.11646/zootaxa.3835.3.1.

Milne-Edwards H. 1857. Histoire Naturelle des Coralliaires ou Polypes Proprement Dits. Vol. 1. Librairie. Paris: Librairie Encylopédique de Roret DOI:10.5962/bhl.title.11574.

Mitsuhashi M, and Chan T-Y. 2006. A new genus and species of deep-water pontoniine shrimp (Decapoda, Caridea, Palaemonidae) from Taiwan. Zoosystema 28:389-398.

Okuno J. 2017. Designation of a new genus Michaelimenes (Decapoda: Caridea: Palaemonidae), with new host record and range extension of its type species, M. perlucidus (Bruce, 1969). Nauplius 25:e2017013 DOI:10.1590/2358-2936e2017013.

Olivier AG. 1811. Suite de l'introduction à l'histoire naturelle des insectes. Palèmon. In: Olivier AG, ed. Encyclopédie méthodique Histoire naturelle Insectes. Paris: H. Agasse, Imprimeur-Libraire, 656670.

Palumbi S, Martin A, Romano S, Mcmillan WO, Stice L, and Grabowski G. 2002. The simple fool 's guide to PCR. version 2.0. Honolulu: Department of Zoology and Kewalo Marine Laboratory, University of Hawaii.

Park J-H, De Grave S, and Kim W. 2019a. A new species of the genus Cristimenes Duriš \& Horká, 2017 (Decapoda, Caridea, Palaemonidae). Zookeys 852:53-71 DOI:10.3897/zookeys.852.34959.

Park J-H, De Grave S, and Kim W. 2019b. On the systematic status of Isopericlimenaeus Marin, 2012 and its type species, Periclimenaeus gorgonidarum (Balss, 1913) (Crustacea: Decapoda: Palaemonidae). Zootaxa 4614:353-367 DOI:10.11646/zootaxa.4614.2.5.

Paul'son O. 1875. Studies on Crustacea of the Red Sea with notes regarding other seas. Part 1 Podophthalmata and Edriophthalmata (Cumacea) [in Russian]. Kiev: S. V. Kul'zhenko.

Rafinesque CS. 1815. Analyse de la nature ou tableau de l'univers et des corps organisés. Palermo.

Rebstock GA, Kang YS. 2003. A comparison of three marine ecosystems surrounding the Korean peninsula: Responses to climate change. Progress in Oceanography 59:357-379 DOI:10.1016/j.pocean.2003.10.002.

Silberfeld E. 1909. Diagnosen neuer japanischer Antipatharien aus der Sammlung von Herrn Prof Doflein (München). Zoologischer Anzeiger 34:760-763.

Thiele J. 1898. Studien über pazifische Spongien. I. Japanische Demospongien. Zoologica: OriginalAbhandlungen aus dem Gesamtgebiete der Zoologie. Stuttgart 24:1-72.

Peer] reviewing PDF | (2020:06:50042:2:0:NEW 19 Sep 2020) 
621 Wang Y-R, Chan T-Y, and Sha Z-L. 2015. A new deep-sea species of the genus Urocaridella (Crustacea:

622

623 Decapoda: Caridea: Palaemonidea) from Yap Seamount in the Western Pacific. Zootaxa 4012:191-197 DOI:10.11646/zootaxa.4012.1.11.

624

625

626

Wicksten MK. 1995. Within-species variation in Periclimenes yucatanicus (Ives), with taxonomic remarks on P. pedersoni Chace (Crustacea: Decapoda: Caridea: Palaemonidae). Proceedings of the Biological Society of Washington 108:458-464. 
627 Figure 1 Map of Indo West Pacific Ocean (IWP). Map showing (A) distribution of Mesopontonia

628

629

630

631

632

633

634

635

636

637

638

639

640 species, (B) location of Jejudo Island, and (C) the type locality of M. kimwoni sp. nov.

Figure 2 Mesopontonia verrucimanus Bruce, 1996, habitus, lateral view. (A) Ovigerous female, pocl 3.7 mm (NIBRIV0000862989); (B) male, pocl 3.2 mm (NIBRIV0000862991).

Figure 3 Mesopontonia verrucimanus Bruce, 1996. (A) Frontal margin and rostrum, lateral view; (B, C) same, lateral view; (D) same, lateral view; (E) telson and uropods, dorso-lateral view; (F) distal end of telson, dorsal view. (A, E, F) Ovigerous female, pocl $3.8 \mathrm{~mm}$ (NIBRIV0000862990); (B) Male, pocl 2.7 mm (NIBRIV0000862982); (C) Female, 2.78 mm (NIBRIV0000862978); (D) Male, pocl 2.5 mm (SNU KR JH1095).

Figure 4 Mesopontonia verrucimanus Bruce, 1996. (A) Left eye, dorsal view; (B) left antennule, dorsal view; (C) left antenna, dorsal view; (D) left third maxilliped. (A-C) Ovigerous female, pocl $3.8 \mathrm{~mm}$

641

642

643

644

645

646 (NIBRIV0000862990); (D) Ovigerous female, pocl 3.7 mm (NIBRIV0000862989).

Figure 5 Mesopontonia verrucimanus Bruce, 1996, ovigerous female, pocl $3.7 \mathrm{~mm}$ (NIBRIV0000862989). (A) Left first pereiopod. (B) same, chela; (C) major right second pereiopod; (D) same, chela and carpus; (E) same, fingers; (F) minor left second pereiopod; (G) same, chela.

Figure 6 Mesopontonia verrucimanus Bruce, 1996, ovigerous female, pocl $3.7 \mathrm{~mm}$ (NIBRIV0000862989). (A) Left third pereiopod; (B) same, dactylus and distal propodus; (C) left fourth pereiopod; (D) same, dactylus and distal propodus; (E) left fifth pereiopod; (F) same, dactylus and distal propodus.

Figure 7 Mesopontonia verrucimanus Bruce, 1996 on Ellisella limbaughi Bayer \& Deichmann, 1960 from Munseom Islet, Jejudo Island. (A) Female specimen, pocl 2.5 mm (MADBK 120533_004); (B) male specimens, pocl 3.0 mm (MADBK 120533_003). Photographic Credits: (A) Jin-Ho Park, (B) Jong Moon Choi.

Figure 8 Mesopontonia kimwoni sp. nov., habitus, lateral view. Holotype, ovigerous female, pocl 2.5 mm (NIBRIV0000862985).

Figure 9 Mesopontonia kimwoni sp. nov., ovigerous female pocl $2.5 \mathrm{~mm}$ (NIBRIV0000862985), holotype. (A) frontal margin and rostrum, lateral view; (B) frontal region, dorsal view; (C) left eye, dorsal view; (D) left antenna, ventral view; (E) telson and uropod, dorsal view; (F) distal end of telson, dorsal view; (G) left third maxilliped, mesial view.

Figure 10 Mesopontonia kimwoni sp. nov., ovigerous female pocl 2.5 mm (NIBRIV0000862985), holotype. (A) left first pereiopod; (B) same, chela; (C) major right second pereiopod; (D) same, chela and carpus; (E) same, fingers; (F) minor left second pereiopod; (G) same, chela.

Figure 11 Mesopontonia kimwoni sp. nov., ovigerous female pocl 2.5 mm (NIBRIV0000862985), holotype. (A) left third pereiopod; (B) same, dactylus and distal propodus; (C) left fourth pereiopod; (D) same, dactylus and distal propodus; (E) left fifth pereiopod.

Figure 12 Mesopontonia kimwoni sp. nov. from Munseom Islet, Jejudo Island. Holotype, ovigerous female, pocl 2.5 mm (NIBRIV0000862985). Photographic credit: Jin-Ho Park. 
676 Figure 13 Artistic interpretation of Mesopontonia kimwoni sp. nov. Holotype, ovigerous female, pocl

677

678

679

680

681

682

683

684

685

686

687

688

689

690

691

692

693

694

695

\author{
2.5 mm (NIBRIV0000862985). Painting by Kyoung Kim.
}

Figure 14 Habitat and host of Mesopontonia from Munseom Islet, Jejudo Island, Korea. Habitat and host specimens of $M$. verrucimanus (A, B) and M. kimwoni sp. nov. (C). (A) host sea whip, Ellisella cf. limbaughi and habitat in depth of $57 \mathrm{~m}$; (B) host sponge Raspailia (Raspaxilla) hirsuta and habitat in depth of $55 \mathrm{~m}$; (C) host black coral Myriopathes lata and habitat in depth of 55m. Photographic Credits: Jong Moon Choi.

Figure 15 Phylogenetic tree obtained by the Maximum likelihood (ML) analysis based on the combined dataset for $\mathrm{COI}$ and 16S sequences. Numbers at nodes represent Maximum Likelihood bootstrap percentage (above) and Bayesian posterior probabilities (below), numbers less than $75 \%$ are not shown.

Table 1: Species used in the phylogenetic analysis with GenBank accession numbers and source. Used symbols: N/A - not available.

Table 2: Pairwise distances of COI sequences and selected morphological characteristics for specimens used in the analysis. (P2 - second pereiopods). 


\section{Table $\mathbf{1}$ (on next page)}

Species used in the phylogenetic analysis with GenBank accession numbers and source. Used symbols: N/A - not available. 
1 Table 1:

2 Species used in the phylogenetic analysis with GenBank accession numbers and source. Used symbols: N/A - not available.

\begin{tabular}{|c|c|c|c|c|c|}
\hline \multirow[t]{2}{*}{ Species } & \multirow[t]{2}{*}{ Voucher ID } & \multirow[t]{2}{*}{ Location } & \multicolumn{2}{|c|}{ GenBank accession number } & \multirow[t]{2}{*}{ Sources } \\
\hline & & & COI & $16 S$ & \\
\hline Mesopontonia kimwoni sp. nov. (1) & NIBRIV0000862985 & Korea & MT311866 & MT311974 & Present study \\
\hline M. kimwoni sp. nov. (2) & NIBRIV0000862994 & Korea & MT311865 & MT311973 & Present study \\
\hline M. verrucimanus (1) & NIBRIV0000862999 & Korea & MT311867 & MT311975 & Present study \\
\hline M. verrucimanus (2) & NIBRIV0000862991 & Korea & MT311868 & MT311976 & Present study \\
\hline M. verrucimanus (3) & NIBRIV0000862990 & Korea & MT311869 & MT311977 & Present study \\
\hline M. verrucimanus (4) & SNU KR JH1095 & Korea & MT311870 & MT311978 & Present study \\
\hline M. verrucimanus (5) & MADBK 120533_007 & Korea & MT311871 & МT311979 & Present study \\
\hline Paraclimenes sp. (1) & SNU-KR_JH357 & Korea & MT311872 & МT311980 & Present study \\
\hline Paraclimenes sp. (2) & SNU-KR-JH466 & Korea & MT311873 & МT311981 & Present study \\
\hline Altopontonia disparostris & RMNH.CRUS.D. 51028 & Norfolk Ridge & KM921671 & KU064797 & Horká et al. 2016 \\
\hline Cuapetes tenuipes & UO V08-48 & Vietnam & KU064965 & KU064814 & Horká et al. 2016 \\
\hline Palaemonella rotumana & MTQ W-33176 & Australia & KR088755 & KU064830 & Horká et al. 2016 \\
\hline Anchistioides willeyi & SNU-Pal_Pal12 & Palau & МT311864 & MT311972 & Present study \\
\hline Lipkemenes lanipes & SNU-PH_PH99 & Philippines & MT311863 & МT311971 & Present study \\
\hline Thaumastocaris streptopus & SNU-TW_TW62 & Taiwan & MT311862 & MK602867 & Present, Park et al. 2019 \\
\hline Bathymenes aleator & บO-948 & Papua New Guinea & MK940921 & MK940946 & Ďuriš \& Šobáňová 2020 \\
\hline Echinopericlimenes aurorae & UO-1057 & Philippines & MK940923 & MK940948 & Ďuriš \& Šobáňová 2020 \\
\hline Echinopericlimenes dentidactylus & UO-1059 & Philippines & MK940930 & MK940954 & Ďuriš \& Šobáňová 2020 \\
\hline Echinopericlimenes calcaratus & UO-960 & Papua New Guinea & MK940925 & MK940949 & Ďuriš \& Šobáňová 2020 \\
\hline Periclimenes laccadivensis & UO-881 & Papua New Guinea & MK940931 & MK940955 & Ďuriš \& Šobáňová 2020 \\
\hline Periclimenes uniunguiculatus & UO-586 & Papua New Guinea & MK940932 & MK940956 & Ďuriš \& Šobáňová 2020 \\
\hline Stenopus hispidus (outgroup) & UO V10-17 & Vietnam & KJ690260 & KU064859 & Horká et al. 2016 \\
\hline
\end{tabular}




\section{Table 2 (on next page)}

Pairwise distances of $\mathrm{COI}$ sequences and selected morphological characteristics for specimens used in the analysis. (P2 - second pereiopods). 


\section{Table 2:}

Pairwise distances of $\mathrm{COI}$ sequences and selected morphological characteristics for specimens used in the analysis. (P2 second pereiopods).

\begin{tabular}{|c|c|c|c|c|c|c|c|c|c|}
\hline & Species & Rostral & Shape and size of P2 & 1 & 2 & 3 & 4 & 5 & 6 \\
\hline 1 & $\begin{array}{c}\text { M. kimwoni sp. nov. } \\
\text { (1) }\end{array}$ & $1-8 / 2$ & Unequal and dissimilar & & & & & & \\
\hline 2 & $\begin{array}{c}\text { M. kimwoni sp. nov. } \\
\text { (2) }\end{array}$ & $1-8 / 2$ & Unequal and dissimilar & 0.011 & & & & & \\
\hline 3 & M. verrucimanus (1) & $1-8 / 1$ & Unequal and dissimilar & 0.142 & 0.1360 & & & & \\
\hline 4 & M. verrucimanus (2) & $1-8 / 0$ & Equal and similar & 0.1380 & 0.1320 & 0.0030 & & & \\
\hline 5 & M. verrucimanus (3) & $1-9 / 0$ & Unequal and dissimilar & 0.1380 & 0.1320 & 0.0030 & 0.0000 & & \\
\hline 6 & M. verrucimanus (4) & $2-8 / 1$ & Unequal and dissimilar & 0.1400 & 0.1340 & 0.0050 & 0.0020 & 0.0020 & \\
\hline 7 & M. verrucimanus (5) & $1-9 / 2$ & Equal and similar & 0.1380 & 0.1320 & 0.0030 & 0.0000 & 0.0000 & 0.0020 \\
\hline
\end{tabular}


Figure 1

Map of Indo West Pacific Ocean (IWP).

Map showing (A) distribution of Mesopontonia species, (B) location of Jejudo Island, and (C) the type locality of $M$. kimwoni sp. nov.

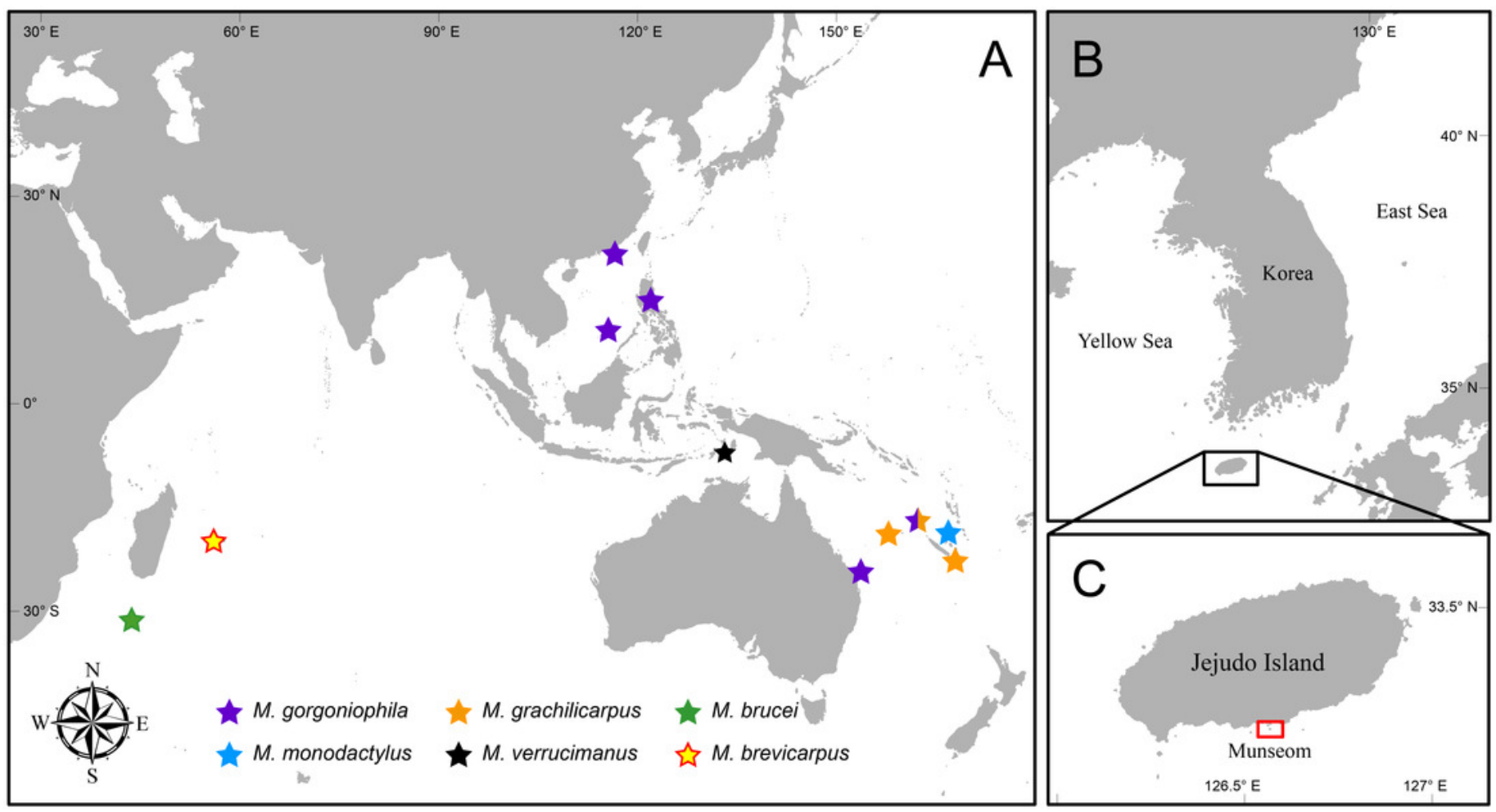


Figure 2

Mesopontonia verrucimanus Bruce, 1996, habitus, lateral view.

(A) Ovigerous female, pocl $3.7 \mathrm{~mm}$ (NIBRIV0000862989); (B) male, pocl $3.2 \mathrm{~mm}$ (NIBRIV0000862991). 


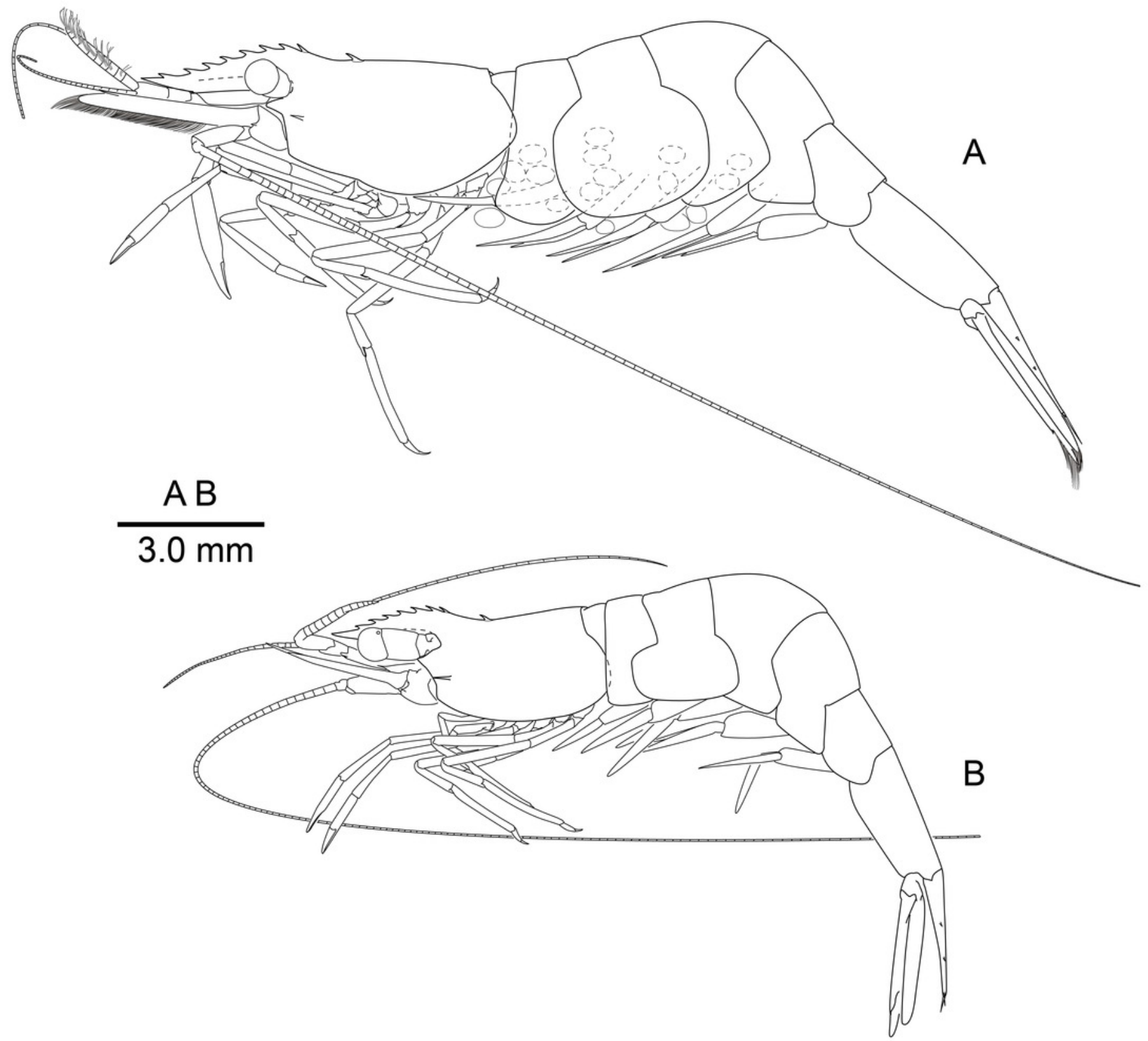




\section{Figure 3}

Mesopontonia verrucimanus Bruce, 1996.

(A) Frontal margin and rostrum, lateral view; (B, C) same, lateral view; (D) same, lateral view;

(E) telson and uropods, dorso-lateral view; $(F)$ distal end of telson, dorsal view. $(A, E, F)$

Ovigerous female, pocl $3.8 \mathrm{~mm}$ (NIBRIV0000862990); (B) Male, pocl $2.7 \mathrm{~mm}$

(NIBRIV0000862982); (C) Female, 2.78 mm (NIBRIV0000862978); (D) Male, pocl $2.5 \mathrm{~mm}$ (SNU KR JH1095). 

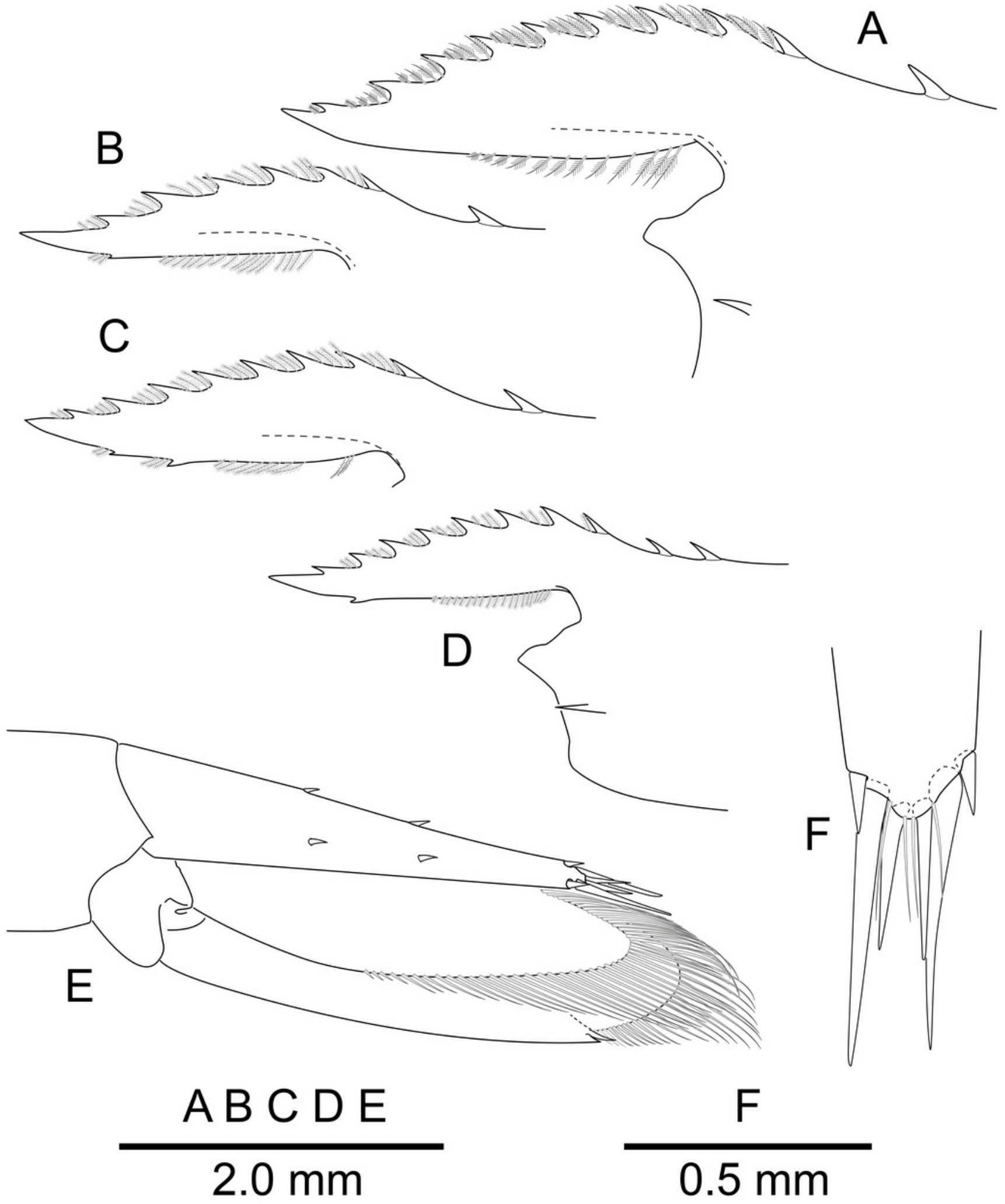
Figure 4

Mesopontonia verrucimanus Bruce, 1996.

(A) Left eye, dorsal view; (B) left antennule, dorsal view; (C) left antenna, dorsal view; (D) left third maxilliped. (A-C) Ovigerous female, pocl 3.8 mm (NIBRIV0000862990); (D) Ovigerous female, pocl $3.7 \mathrm{~mm}$ (NIBRIV0000862989). 

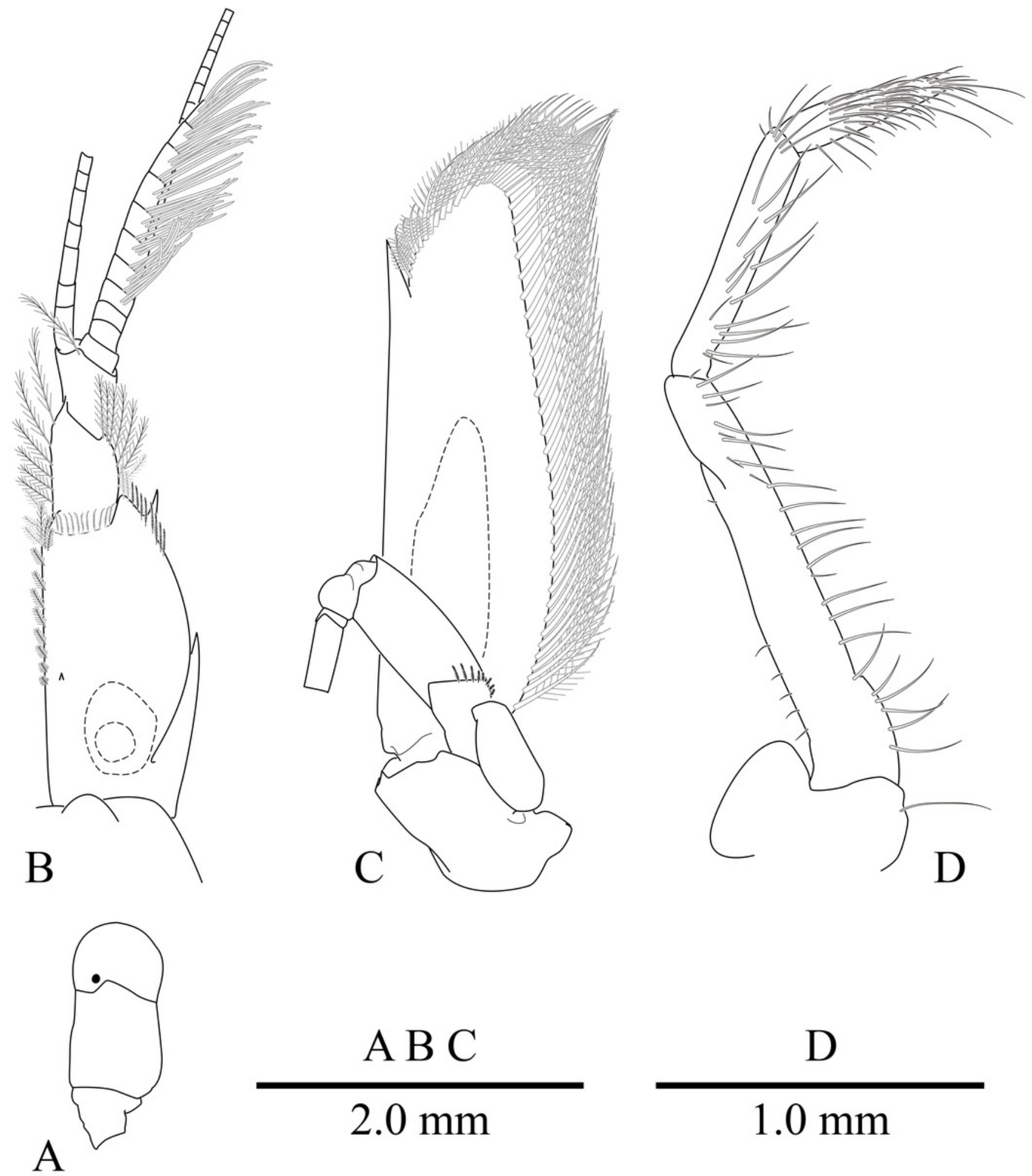
Figure 5

Mesopontonia verrucimanus Bruce, 1996, ovigerous female, pocl $3.7 \mathrm{~mm}$ (NIBRIV0000862989).

(A) Left first pereiopod. (B) same, chela; (C) major right second pereiopod; (D) same, chela and carpus; (E) same, fingers; (F) minor left second pereiopod; (G) same, chela. 


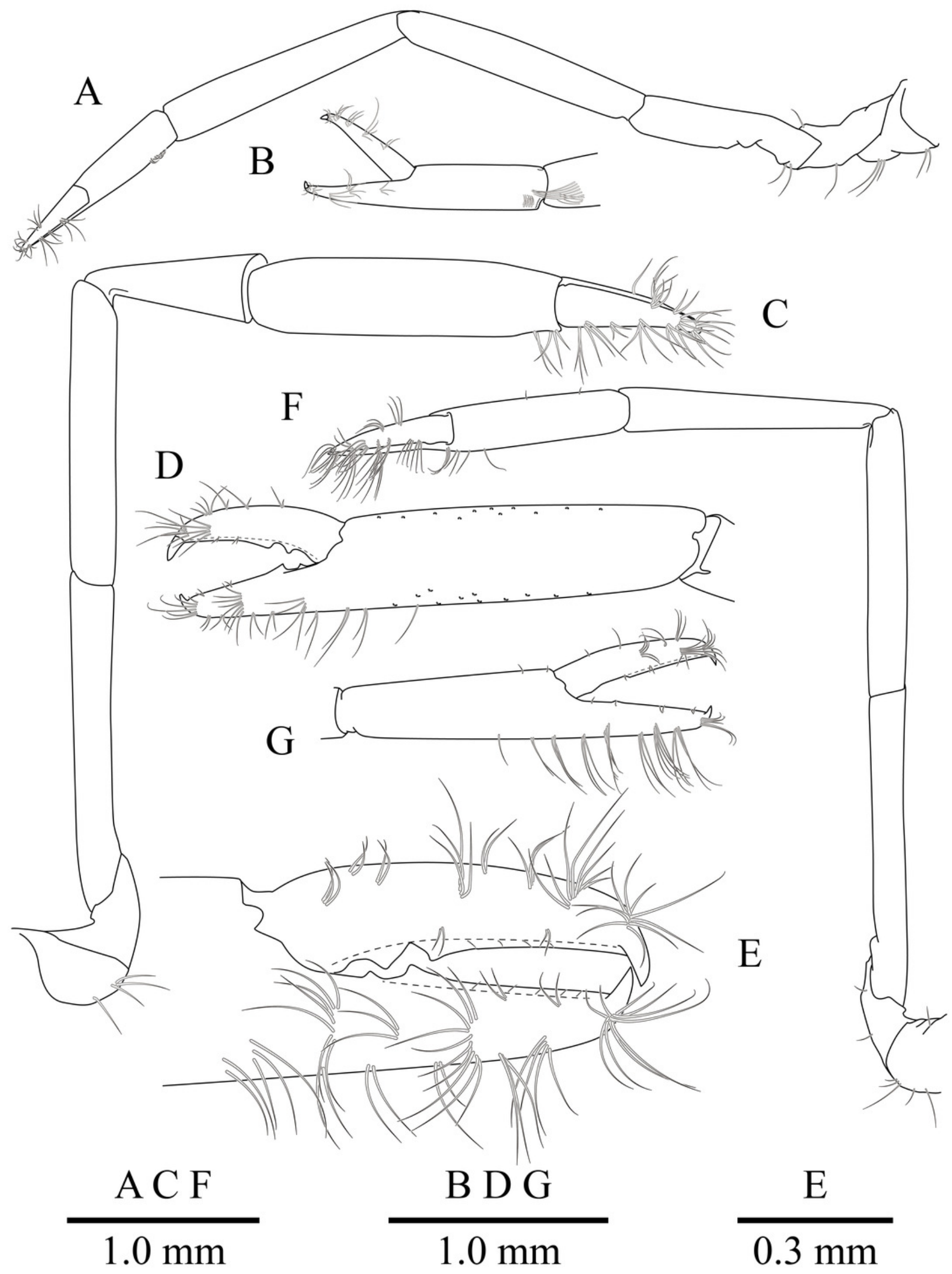

Peer) reviewing PDF | (2020:06:50042:2:0:NEW 19 Sep 2020) 
Figure 6

Mesopontonia verrucimanus Bruce, 1996, ovigerous female, pocl $3.7 \mathrm{~mm}$ (NIBRIV0000862989).

(A) Left third pereiopod; (B) same, dactylus and distal propodus; (C) left fourth pereiopod; (D) same, dactylus and distal propodus; (E) left fifth pereiopod; (F) same, dactylus and distal propodus. 


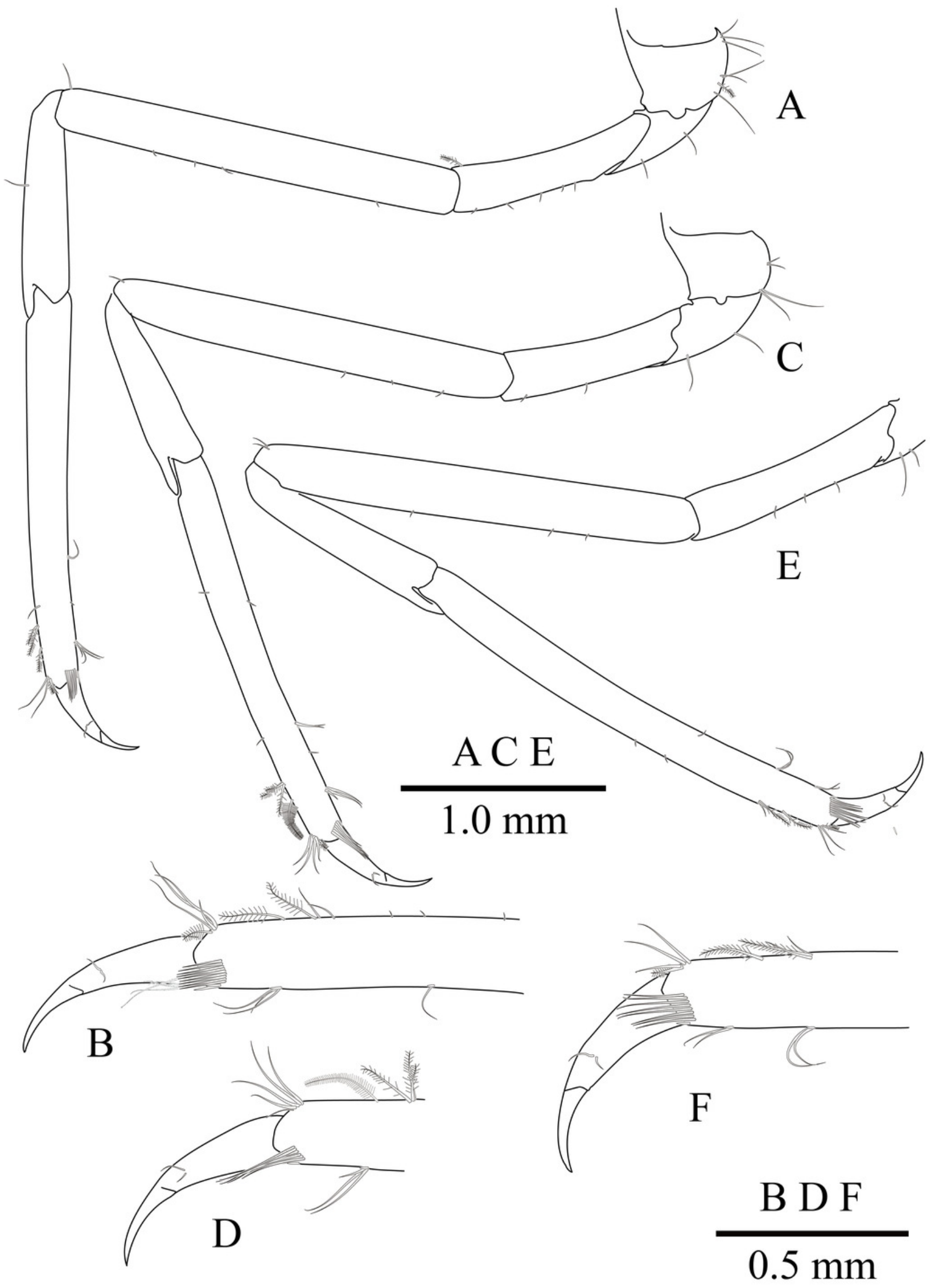


Figure 7

Mesopontonia verrucimanus Bruce, 1996 on Ellisella limbaughi Bayer \& Deichmann, 1960 from Munseom Islet, Jejudo Island.

(A) Female specimen, pocl 2.5 mm (MADBK 120533_004); (B) male specimens, pocl $3.0 \mathrm{~mm}$ (MADBK 120533_003). Photographic Credits: (A) JH Park, (B) JM Choi. 

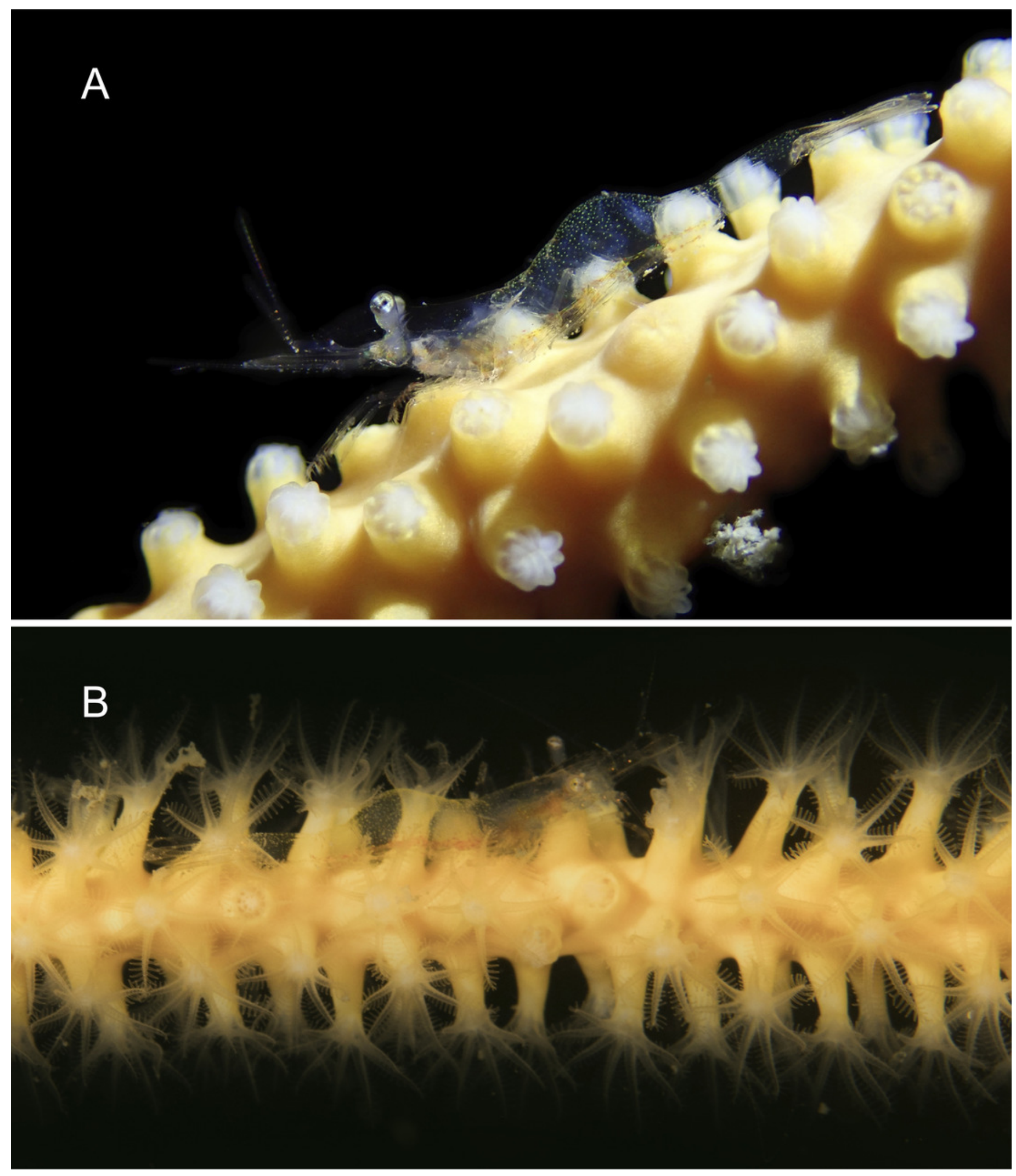
Figure 8

Mesopontonia kimwoni sp. nov., habitus, lateral view.

Holotype, ovigerous female, pocl 2.5 mm (NIBRIV0000862985).

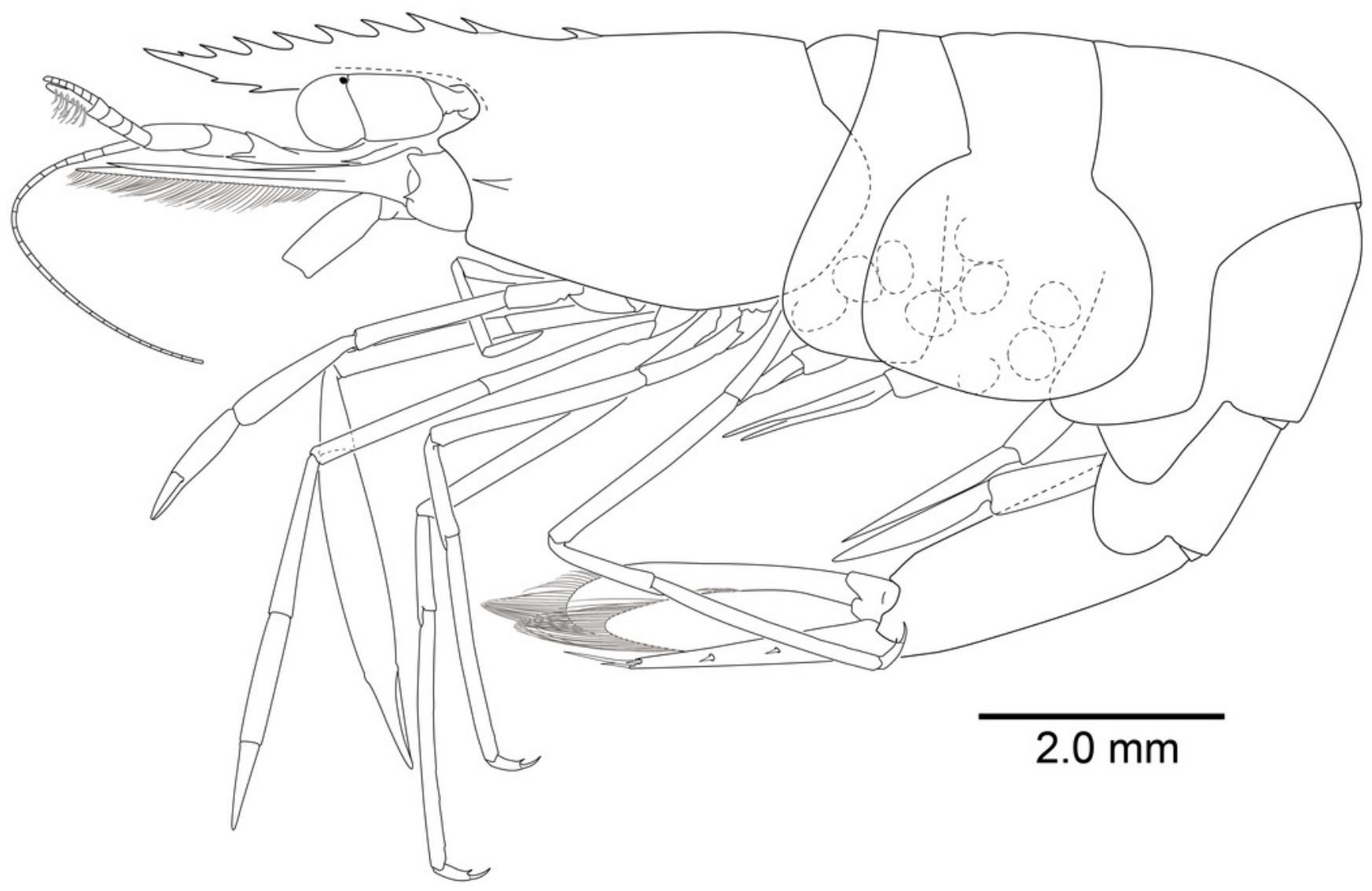


Figure 9

Mesopontonia kimwoni sp. nov., ovigerous female pocl 2.5 mm (NIBRIV0000862985), holotype.

(A) frontal margin and rostrum, lateral view; (B) frontal region, dorsal view; (C) left eye, dorsal view; (D) left antenna, ventral view; (E) telson and uropod, dorsal view; (F) distal end of telson, dorsal view; (G) left third maxilliped, mesial view. 

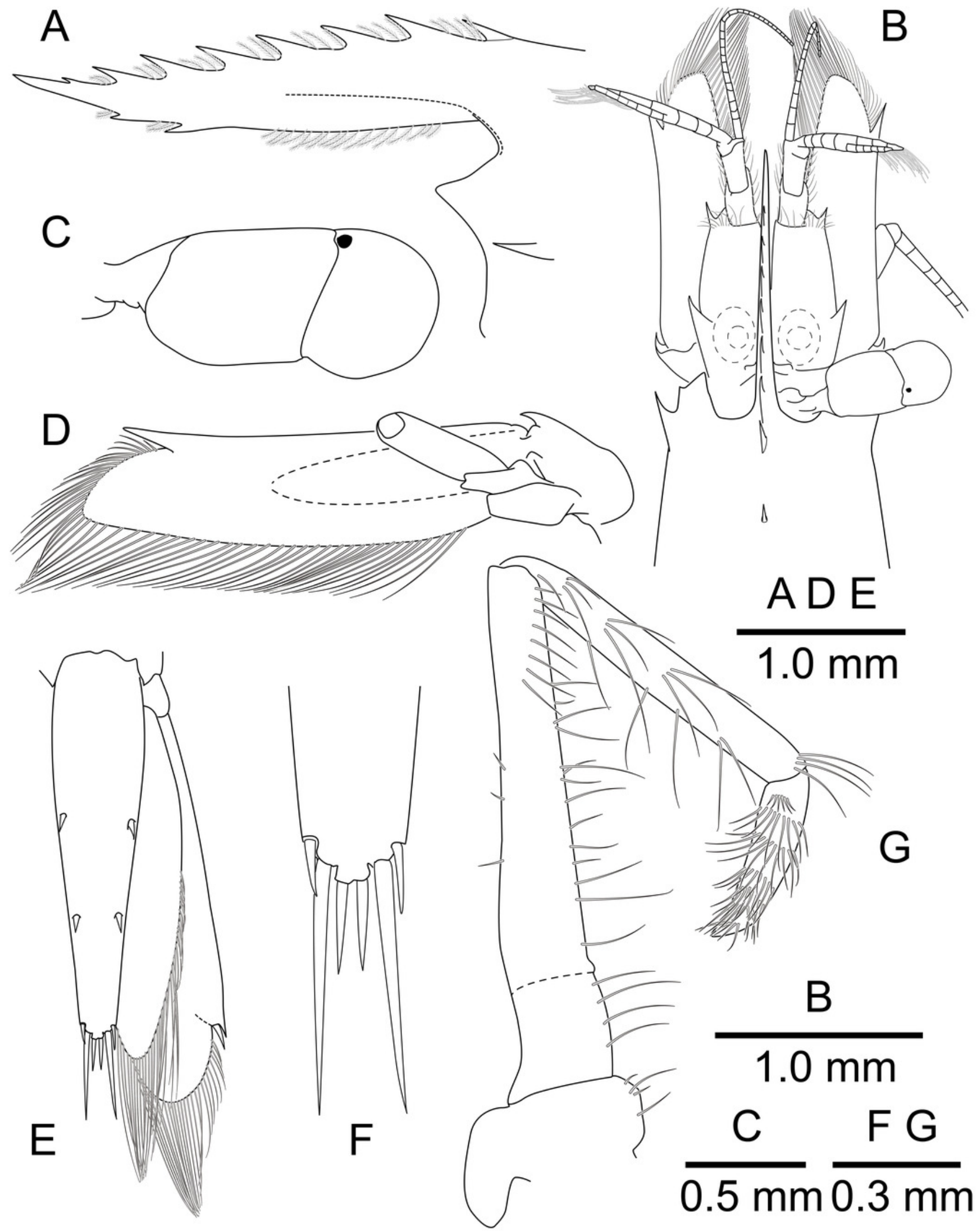


\section{Figure 10}

Mesopontonia kimwoni sp. nov., ovigerous female pocl 2.5 mm (NIBRIV0000862985), holotype.

(A) left first pereiopod; (B) same, chela; (C) major right second pereiopod; (D) same, chela and carpus; (E) same, fingers; (F) minor left second pereiopod; (G) same, chela. 

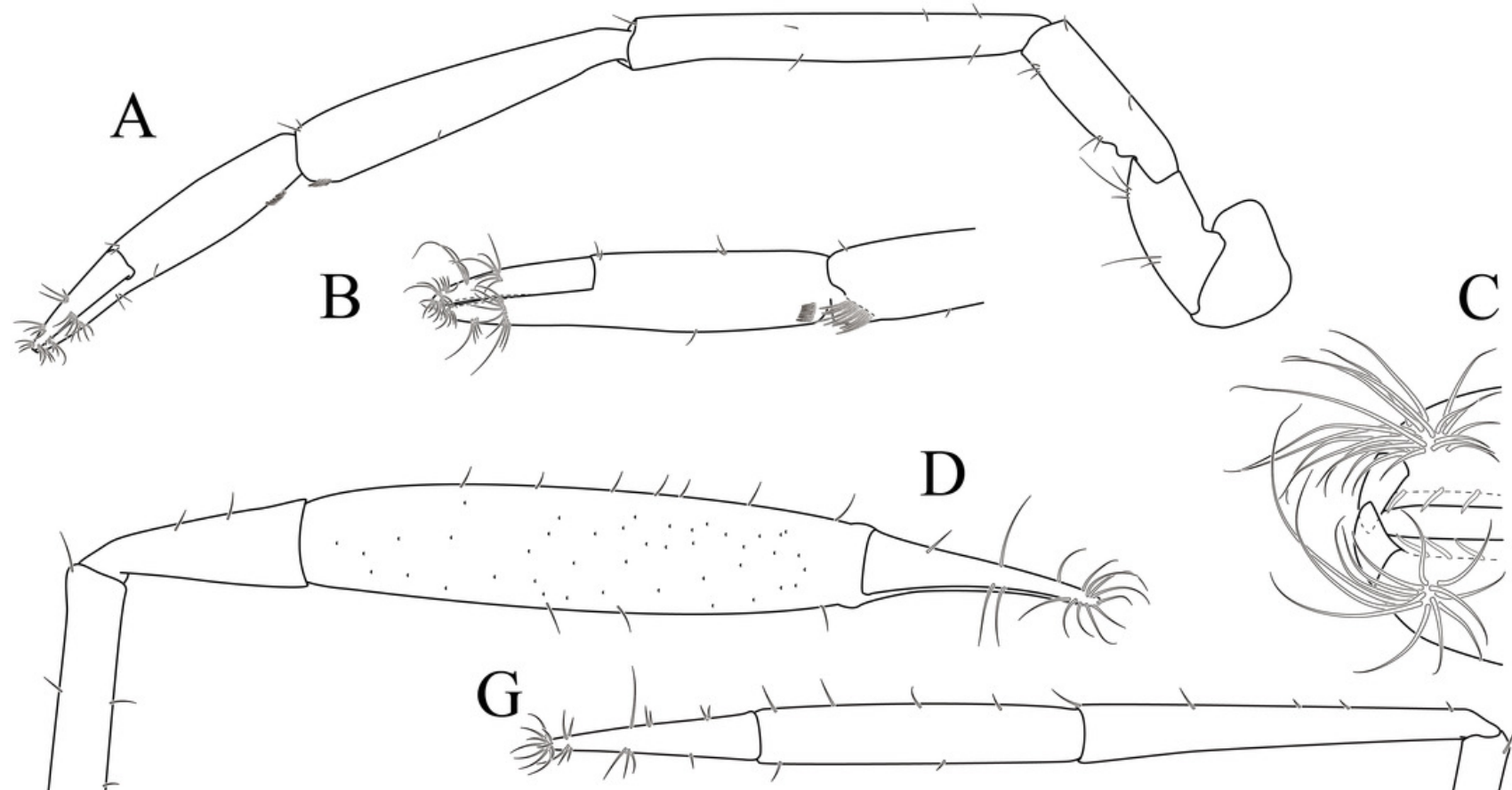

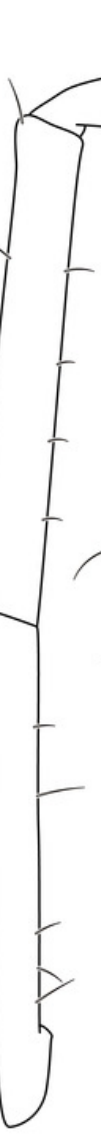

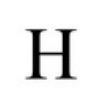

$\mathrm{H}$

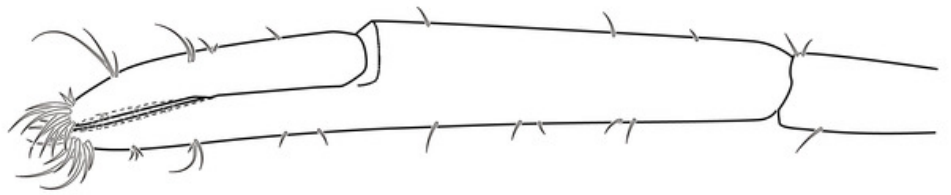

E


N

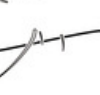

$\because, '$,

\section{.}

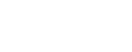


Figure 11

Mesopontonia kimwoni sp. nov., ovigerous female pocl 2.5 mm (NIBRIV0000862985), holotype.

(A) left third pereiopod; (B) same, dactylus and distal propodus; (C) left fourth pereiopod; (D) same, dactylus and distal propodus; (E) left fifth pereiopod. 


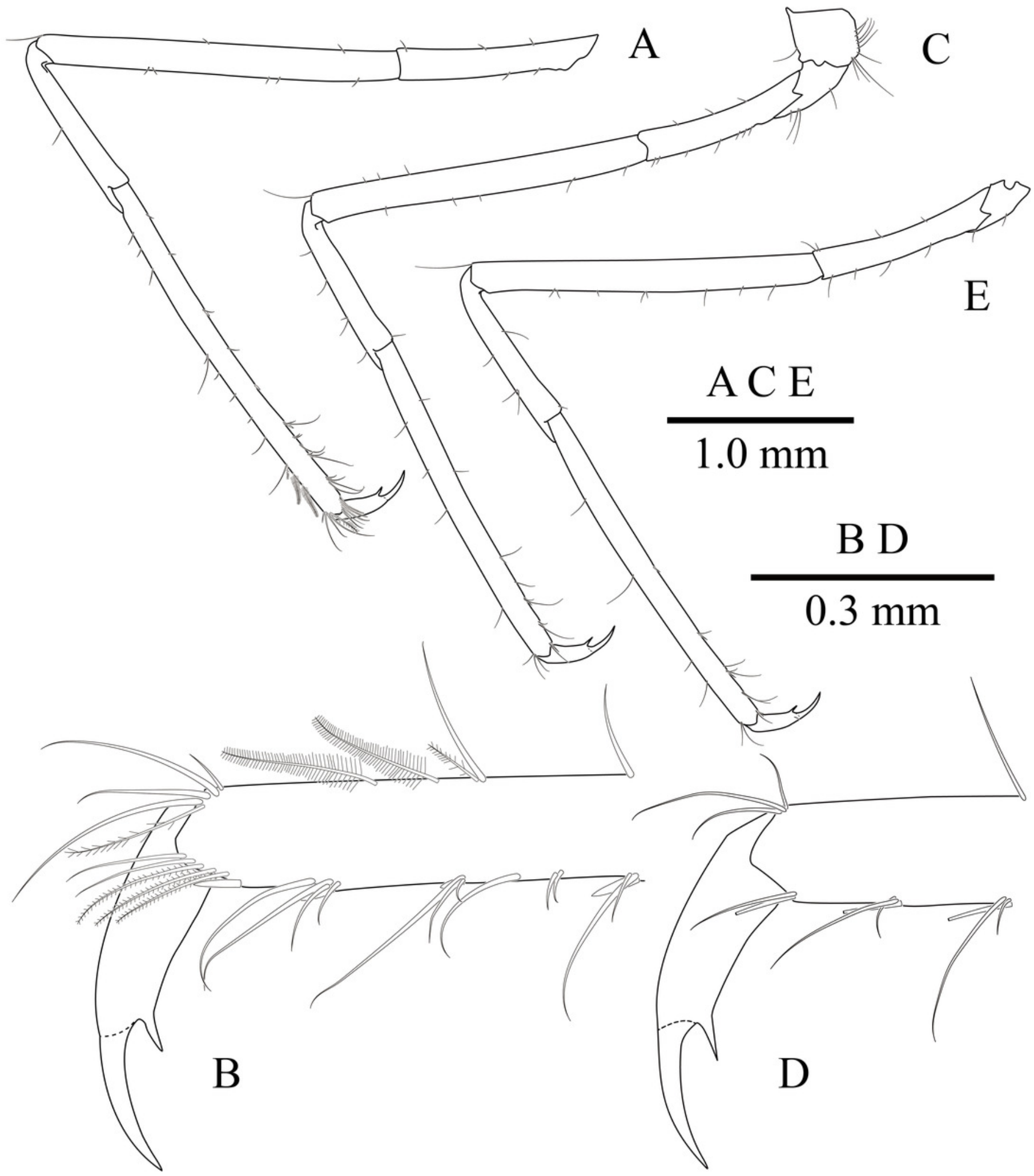




\section{Figure 12}

Mesopontonia kimwoni sp. nov. from Munseom Islet, Jejudo Island.

Holotype, ovigerous female, pocl 2.5 mm (NIBRIV0000862985). Photographic credit: JH Park.

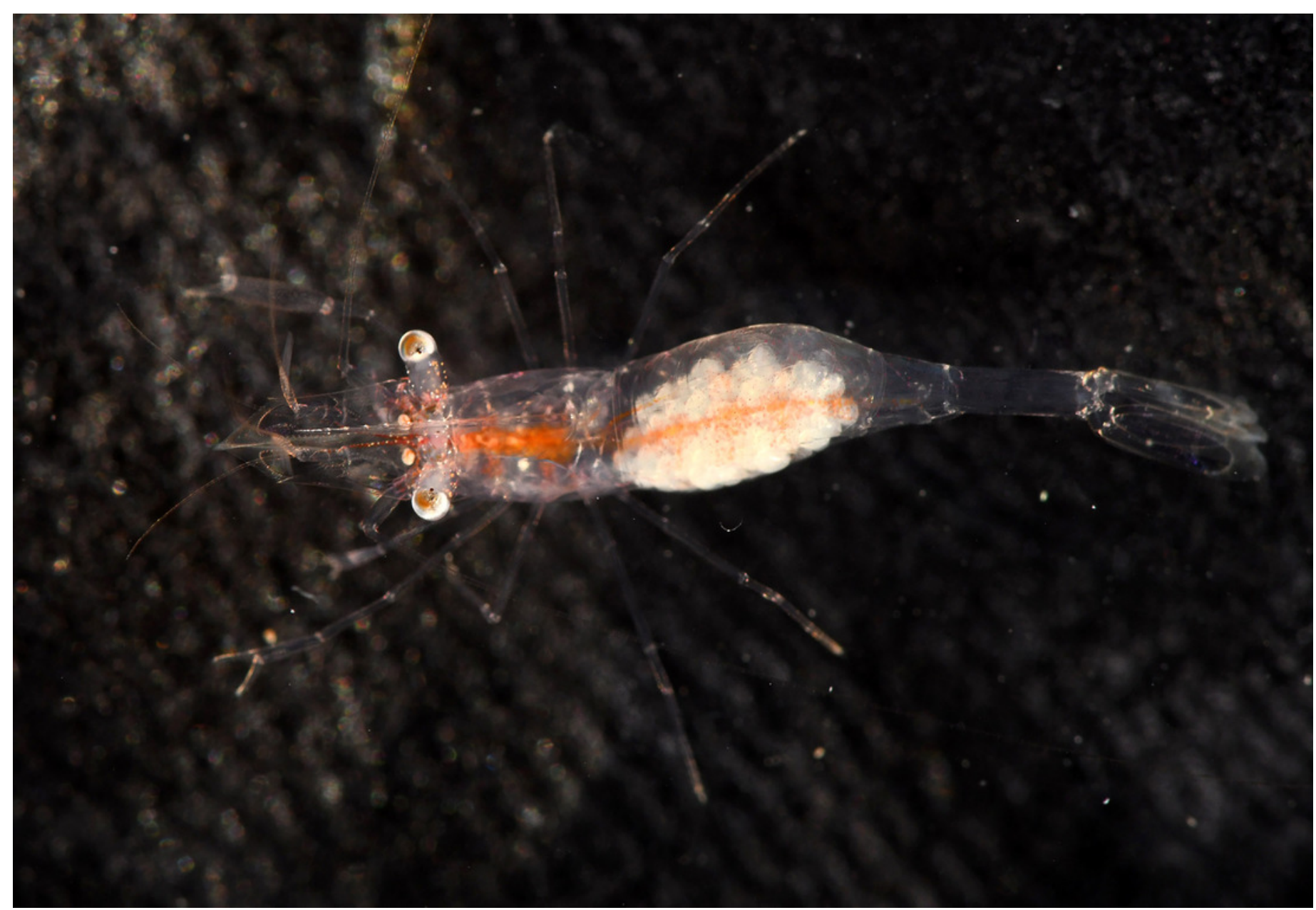


Figure 13

Artistic interpretation of Mesopontonia kimwoni sp. nov.

Holotype, ovigerous female, pocl 2.5 mm (NIBRIV0000862985). Painting by YK Kim.

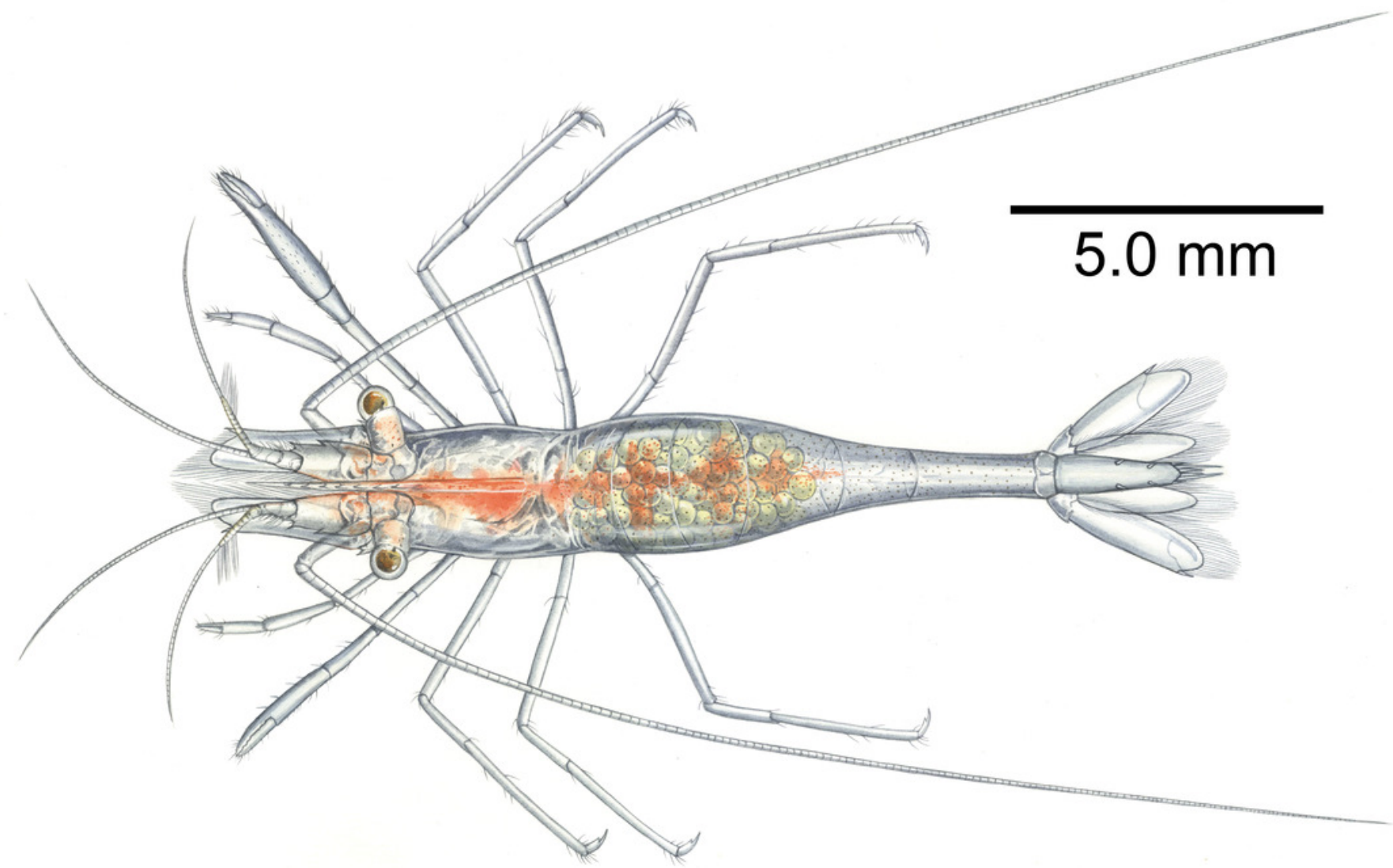




\section{Figure 14}

Habitat and host of Mesopontonia from Munseom Islet, Jejudo Island, Korea.

Habitat and host specimens of $M$. verrucimanus (A, B) and M. kimwoni sp. nov. (C). (A) host sea whip, Ellisella cf. limbaughi and habitat in depth of $57 \mathrm{~m}$; (B) host sponge Raspailia (Raspaxilla) hirsuta and habitat in depth of $55 \mathrm{~m}$; (C) host black coral Myriopathes lata and habitat in depth of 55m. Photographic Credits: JM Choi. 

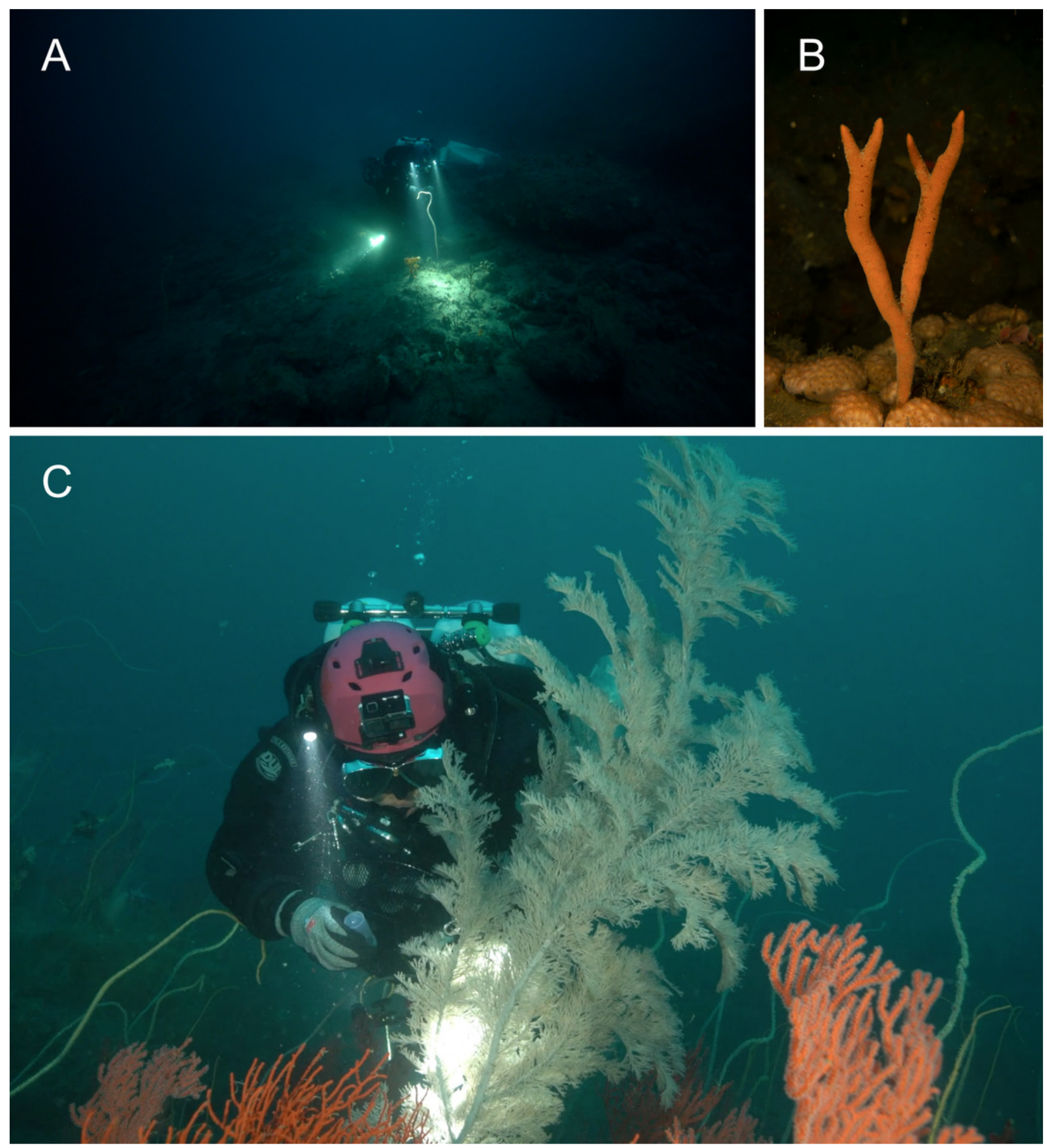


\section{Figure 15}

Phylogenetic tree obtained by the Maximum likelihood ( $\mathrm{ML}$ ) analysis based on the combined dataset for $\mathrm{COI}$ and $16 \mathrm{~S}$ sequences.

Numbers at nodes represent Maximum Likelihood bootstrap percentage (above) and Bayesian posterior probabilities (below), numbers less than $75 \%$ are not shown.

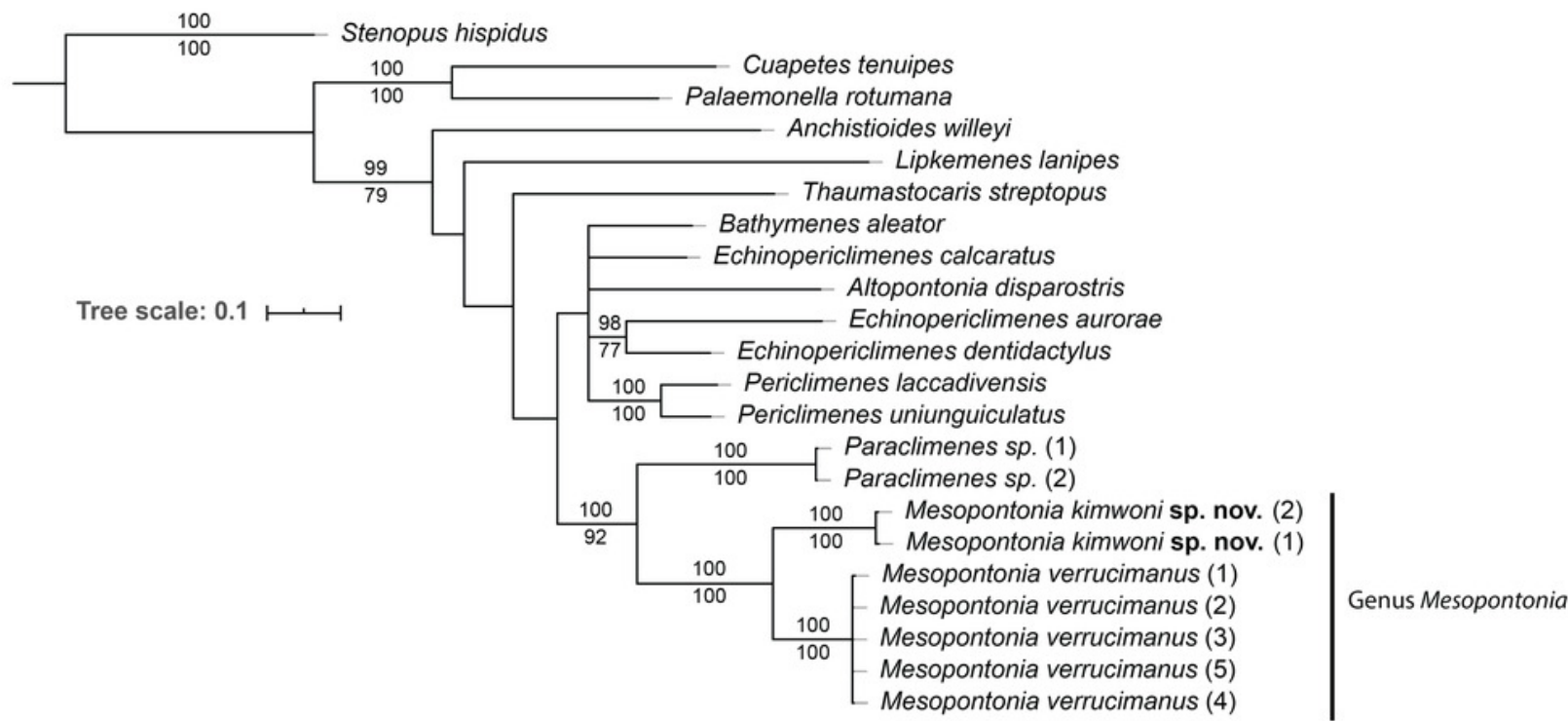

